\title{
INFLUENCE OF NODULE-INDUCING Frankia ON SALINITY TOLERANCE OF Casuarina glauca SIEBER EX SPRING PLANTS AND RHIZOSPHERE REMEDIATION \\ El-Settawy, A.A. A. ${ }^{*}$ and Amal A. S. EL-Gamal ${ }^{*}$ \\ Forestry and Wood Technology Dept., Faculty of Agriculture, Alexandria University, Egypt. \\ ${ }^{*}$ Soil Salinity and Alkalinity Dept. Soil, Water and Environment Institute, Agricultural Research Center, Egypt.
}

\begin{abstract}
This study was carried out to investigate the effect and the role of nitrogenfixing nodules induced by Frankia bacteria on roots growth of Casuarina glauca Sieber ex: Spreng plants in salinity tolerance and soil remediation. This study was carried out at the Experimental Station of Forestry and Wood Technology Department, Faculty of Agriculture, Alexandria University, Alexandria, and model nursery at Wadi El- Natroon Region, Beheira Governorate, Egypt. . Three experiments were carried out as follows:

Experiment 1: Eight $\mathrm{NaCl}$ concentrations (00.00 (S 1$), 1000\left(\mathrm{~S}_{2}\right), 3000\left(\mathrm{~S}_{3}\right), 5000\left(\mathrm{~S}_{4}\right)$, $7000\left(\mathrm{~S}_{5}\right), 10.000\left(\mathrm{~S}_{6}\right), 12.000\left(\mathrm{~S}_{7}\right)$ and $14.000 \mathrm{ppm}\left(\mathrm{S}_{8}\right)$ ) amended to root rhizosphere to pinpoint the maximum salinity level at which $50 \%$ of nodulated and unnodulated plants can survive.

Experiment 2: In this experiment split-root technique was applied using doublecontainer foam pots.

Experiment 3: This experiment was conducted to study the effect of nodule diameter on salt tolerance and growth of the host and remediation of saline soil. In the first experiment, it was found that the nodulated plants had higher salinity tolerance than that of unnodulated ones. However, nodulated plants showed $40 \%$ survival at $S_{7}$, while unnodulated plant reached this survival percent at $S_{6}$. It was noticed that the growth rate of nodulated plants was significantly higher than that of unnodulated ones at $\mathrm{S}_{4}$ up $\mathrm{S}_{8}$. In the second experiment, it was noticed that unnodulated plants displayed the lowest survival (20 and $30 \%$ in first and second season, respectively). Shoot live ratio (SLR) of nodulated root under salinity stress was higher than that of unnodulated ones. However the reaction of nodules to direct salinization as well as the changes of characters of plants bearing it will be described and discussed in details. The results of experiment 3 revealed the direct relationships between nodule diameter and $\mathrm{N}$ content of branchlets and total dry matter under salinity stress. On the other hand, it was found that the higher the nodule diameter, the lower the $\mathrm{EC}, \mathrm{Na}, \mathrm{Cl}$ contents in the rhizosphere obtained. Ultrastrastructural studies of nodules using SEM supported the foregoing results, since the filamentous hyphae of Frankia that colonized nodule cortex became finer and more condensed due to salinity stress. This modification brought forth an increase in surface area of filamentous hyphae to be adapted with saline rhizosphere.
\end{abstract}

\section{INTRODUCTION}

Frankia bacteria are common soil inhabitants distinguished from genera of soil micro-organisms by their ability to nodulate some non-leguminous plants forming actinorhizal root nodules that fix nitrogen. 
The actinorhizal root nodules are induced by the genus Frankia in several woody dicotyledonous plant species belonging to eight different plant families (Pawlowski et al., 1993). Casuarinaceae is an important family, which comprises several fast growing species and can fix significant amount of $\mathrm{N}$ via induced nodules under specific conditions. In addition, casuarinas are economically and ecologically important plants due to their ability to grow in widely different climates, ranging from humid forest to arid and semiarid conditions (Diem and Dommergues, 1983 and Redell et al., 1991). Frankia are particularly hardy species found worldwide in harsh and nutrient-deficient ecosystems (Roy et al., 2007 and_Khamzina et al., 2009).

The ultrastructure of nodule-forming cells are distinguished with forming specialized vesicles (Berry et al., 1993) that furnished an ideal conditions for nitrogenase activity and hence the fixation of the atmospheric nitrogen. Actinorhizal root of Casuarina has specialized structures characterized with filamentous hyphae that intracelluarly localized in nodule cell. The shape and intercellular location of vesicules produced during symbiosis is determined by the host plant (Baker and Mullen, 1992).

The reluctant nature of Frankia in salinized conditions in vitro studies received few attention compared with in vivo studies (Dawson and Gibson, 1987; Balasubramanian et al., 1996 and Tani and Sasakawa, 2000). The effect of applied nitrogen on salinity tolerance was studied (Langdale and Thomas, 1971; KafKafi et al., 1982 and Glass and Siddiqi, 1985), yet quite scarce studies were carried out on nitrogen-fixing plants especially those actinorhizal ones.

This work aimed to study the direct and indirect effects of Frankiainduced nodule on salt tolerance of the host, Casuarina glauca plants using split-root technique as described by Anderson (1975) to pinpoint the actual effect of Frankia. This work aimed also to trace the manner of which the $\mathrm{Na}$ and $\mathrm{Cl}$ undergo in plant and rhizosphere as well as the concomitant remediation. The changes in the ultrastructure of nodules colonized by Frankia under salinity conditions were also studied to elucidate, if any, tolerance of salinity.

\section{MATERIALS AND METHODS}

\section{Preparation of plants}

Fresh seeds were collected in 2004 from a single tree of Casuarina. glauca grown at Experimental Station of Forestry and Wood Tech. Dept., Fac. Agric., Alex Univ,. The seeds were sown in sterilized soil consists 2: I sand and clay. Resultant seedlings were transplanted in polyethylene bags, which contained about $1500 \mathrm{~g}$ of 2:1 clay: soil mixture (w/w).

As the seedlings aged 3 months old, they were artificially inoculated with Frankia inocula (COAAS strain) isolated from stressed Casuarina glauca trees at the Experimental Station of Forestry and Wood Tech. Dept., Fac. Agric, Alex. Univ.) which were previously cultured in Qmod media for 3 months then 10 discs of $0.4 \mathrm{~cm}$ diam. of the culture were incorporated with $100 \mathrm{~g}$ of sterilized slurry mixture of 1: 1 farm yard and peat $(\mathrm{w} / \mathrm{w})$. Each plant 
received about one gram of slurry textured inoculum. The same number of seedlings was also inoculated but with sterilized inocula as a control. After seven months of the inoculation, the inoculated roots of the seedling were examined to check the incidence of nodules. To study the effect of nitrogenfixing nodules on the tolerance of C. glauca seedlings to salinity, all wellnodulated seedlings were separated for the following three experiments:

\section{Experiment (1):}

An experiment was conducted in at the Experimental Station of Forestry and Wood Technology Department, Faculty of Agriculture, Alexandria University, Alexandria in March, 2004. The aim of this experiment is to pinpoint the highest level of salinity that nodulated plants survive or withstand. Nodulated C. glauca plants, aged 10 month old were transplanted in polyethylene bags which contained $1.75 \mathrm{Kg}$ sandy clay soil (2:1). The experimental soil was salinized with eight levels of $\mathrm{Na} \mathrm{Cl}$ as follows: $\left(0.0\left(\mathrm{~S}_{1}\right)\right.$, $1.0\left(\mathrm{~S}_{2}\right), 3.0\left(\mathrm{~S}_{3}\right), 5.0\left(\mathrm{~S}_{4}\right), 7.0\left(\mathrm{~S}_{5}\right), 10\left(\mathrm{~S}_{6}\right), 12\left(\mathrm{~S}_{7}\right)$ and $14 \mathrm{~g}\left(\mathrm{~S}_{8}\right)$ of $\mathrm{NaCl} / \mathrm{kg}$ soil). The salt was previously dissolved in a tap water, then added to the soil, thereafter, the soil was left to be air dried. Five replicates were used for each treatment in complete randomized design (CRD). The obtained data were statistically analyzed as a factorial arrangement of two factors, salinity (8 levels) and nodulation (2 levels), according to Steel and Torrie (1980).

\section{Experiment (2):}

\section{Salinization of rhizosphere using split root technique}

An experiment was conducted in two seasons (March, 2005- Jan.,2006 and March, 2006- Jan., 2007 in a model nursery at Wadi El-Natroon Region, Beheira Governorate) . Apparently homogenous seedlings, with well-formed nodules were transplanted in split-root containers. The split-root container consists of two units, the main- and sub-units (Fig. 1). Each unit contained about $1.25 \mathrm{~kg}$ of 2: I sand: clay soil (w/w). The root system for each plant was divided into two parts then each part was inserted into one container, i.e., one in the main- $(A)$ and the other in the sub-container $(B)$.

The container $(A)$ for all treatments was filled with normal unsalinized soil and the container (B) contained salinized soil (10,000 ppm of $\mathrm{NaCl}$ ). Herewith, five treatments were used as follows:

a) Unnodulated plants, whose root systems are split into two parts, each part grown in a normal soil

(Control treatment);

b) Nodulated plants, whose root systems are divided into two parts (nodulated and unnodilated) each part grown in a normal soil ..(F treatment);

C) Nodulated plants, whose nodulated roots are directly exposed to salinized rhizosphere in container (B) and unnodulated ones is inserted in unsalinized rhizosphere. ...(FIS treatment).

d) Nodulated plants, whose unnodulated roots are directly exposed to salinized rhizosphere (B) and nodulated ones are exposed to normal soil (A) (FOS treatment). 
e) Unnodulated plants, whose one half of the root systems are directly exposed to salinized container (B) and the other ones are inserted in unsalinized container $(A)$.... (S treatment).
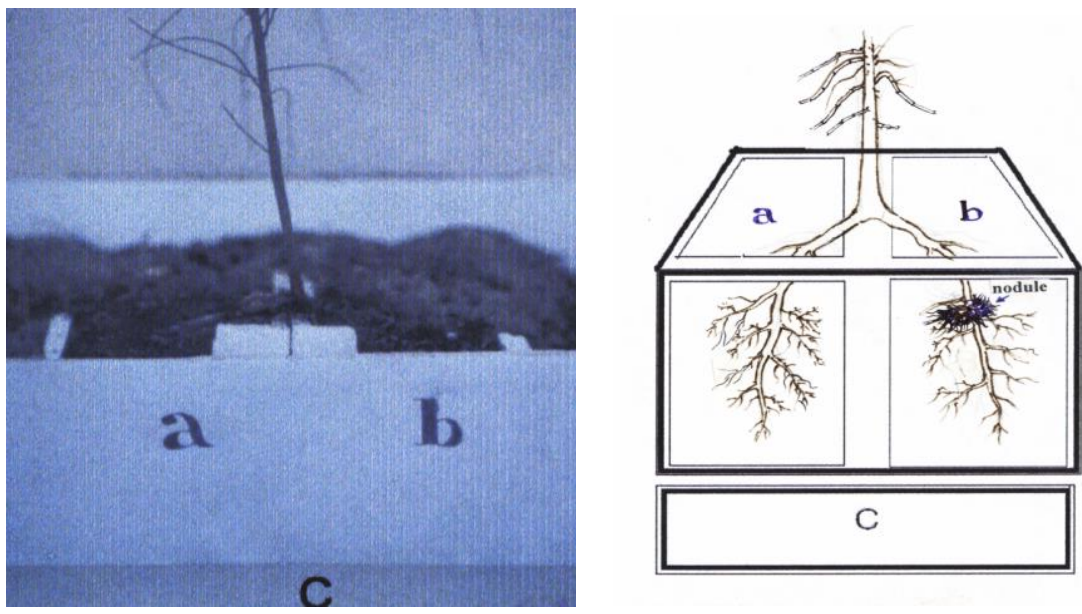

Fig. (1): Split-root double container, comprising main- (A) and subcontainer (b). The part (C) is an acceptor of drained water.

Details of the treatments are set out in Table (1).

Shoot height $(\mathrm{cm})$ of all experimental units as well as nodule diameter $(\mathrm{cm})$ of only nodulated plants were recorded before transplanting and also at the end of the experiment to determine shoot growth rate and increase rate of nodule diameter $(\mathrm{cm} /$ month), respectively. The used experimental design in this experiment was complete randomized design (CRD) according to Steel and Torrie (1980) with ten replicates for each treatment. Comparison among means of the treatments was made using the least significant difference (LSD) multiple range tests.

Table 1: Details of the five experimental units using split root double container that comprised main-(A) and sub container (B).

\begin{tabular}{|l|c|c|c|c|c|c|c|c|c|c|}
\hline \multirow{2}{*}{ Treatment } & \multicolumn{2}{|c|}{ Control } & \multicolumn{2}{c|}{ F } & \multicolumn{2}{c|}{ FIS } & \multicolumn{2}{c|}{ FOS } & \multicolumn{2}{c|}{ S } \\
\cline { 2 - 13 } & A & B & A & B & A & B & A & B & A & B \\
\hline Nodule-bearing root & - & - & - & + & - & + & + & - & - & - \\
\hline Stalinized root & - & - & - & - & - & + & - & + & - & + \\
\hline
\end{tabular}

The sign "(+)" means the presence of nodules or salinized rhizosphere and the sign "(-)" means the absence of nodules or unsalinized rhizosphere.

\section{Experiment (3):}

An experiment was conducted in 2007 to study the relationship between nodule diameter and remediation of rhizosphere as well as $\mathrm{N}$ content and total biomass. Fifteen nodulated plants, bearing nodules ranged between 1.0 to $10.0 \mathrm{~mm}$ in diameter were gently removed from their containers then gently washed free from debris. For each plant, nodule diameter was measured, 
using manual calliper. Nodulated plants were transplanted in salinized soil (containing 10,000 ppm of $\mathrm{NaCl}$ ). The changes of EC value of the soil; $\mathrm{Na}$ and $\mathrm{Cl}$ contents and total dry matter were recorded.

\section{Sampling}

After 6 months of the treatment (exposure of the roots to salinized rhizosphere), the plants were gently separated from the soil then samples of roots and shoots were washed by tap water and oven dried at $70^{\circ} \mathrm{C}$ to a constant weight for determination of dry matter. Diameter $(\mathrm{cm})$ and dry weight (g) of nodules were determined. Diameter of nodule was determined based on the average of diameter recorded at two directions using a manual calliper. The relative weight of nodule (RWN) was calculated using the following equation:

\section{$R W N=\frac{\text { Nodule dry weight }}{\text { Total dry weight of root }}$}

Samples of roots and branchlets were taken for NPKNa and $\mathrm{Cl}$ determination.

Samples of the soil were also obtained from rhizosphere of main- and subunit, oven dried at $70^{\circ} \mathrm{C}$ to determine $\mathrm{N}, \mathrm{P}, \mathrm{K}, \mathrm{Na}$ and $\mathrm{Cl}$ in addition to determine EC values.

\section{Plant analysis}

Nitrogen, phosphorus and potassium were determined in the digest solution as follows:

Total nitrogen of branchlets and roots was determined according to Bremmer and Mulvaney (1982) and phosphorus was determined according to Cottrnie (1980) using Milton Ray Spectronic 2ID. Potassium was determined according to the method described by Cottrnie (1980) in the digest by Fisher scientific flame photometer, LAB 201.

\section{Chemical analysis of the rhizosphere}

\section{Electrical conductivity (EC)}

Soil samples, of $10 \mathrm{~g}$ taken from dried rhizosphere, were extracted by $50 \mathrm{ml}$ of distilled water (1:5 soil: distilled water), filtered with filter paper. The EC of resultant filtrate was measured using CDM83-Conductivity Meter (Rhoades, 1982).

\section{Sodium and chloride contents of the rhizosphere}

Sodium $(\mathrm{Na}+)$ content of rhizosphere was determined in the 1:5 soil: water extract according to Knudsen et al.(1982) using Coming 410 flamephotometer and $\mathrm{Cl}^{-}$was determined volumetrically by $\mathrm{AgNO}_{3}$ method (Rhoades, 1982).

\section{Nitrogen, phosphorus and potassium contents of the rhizosphere}

Total soil nitrogen was determined using the modified Kiejldahl method described by Bremmer and Mulvaney (1982). Phosphorus extractable by sodium bicarbonate was determined by ascorbic acid molybdenum blue method (Olsen and Sommers, 1982) using Milton Roy supertonic 21 D. Exchangeable and soluble potassium was extracted by neutral $1.0 \mathrm{~N}$ 
ammonium acetate followed by centrifugation and decantation as described by Kundsen et al. (1982). Potassium was measured by Fisher Scientific Flame Photometer (Model LAB 201).

Scanning electron micrograph (SEM) examination

Actinorhizal root samples were carefu1ly separated from the salinized and unsalinized rhizosphere, washed free from debris. About $0.2 \mathrm{~g}$ fresh sample of nodule was excised, then subjected to successive series of ethanol concentrations $(10,20,, 10,20, \ldots . .90,100 \%)$ and eventually with xylol solution then fixed for SEM examination in the Central Lab., Fac. Agric., Alex. Univ., Egypt.

\section{RESULTS AND DISCUSSION}

\section{Experiment (1)}

This experiment was carried out to pinpoint the critical salt concentration or lethal salinity level for C. glauca plants, using 8 concentrations of $\mathrm{NaCl}\left(0.0 \mathrm{~g} \mathrm{NaCl} / \mathrm{kg}\right.$ of the soil $\left(S_{1}\right), 1.0 \mathrm{~g} \mathrm{NaCl} / \mathrm{kg}$ of the soil ( $\left.\mathrm{S}_{2}\right), 3 . \mathrm{g} \mathrm{NaCl} / \mathrm{kg}$ of the soil $0\left(\mathrm{~S}_{3}\right), 5.0 \mathrm{~g} \mathrm{NaCl} / \mathrm{kg}$ of the soil $\left(\mathrm{S}_{4}\right), 7.0 \mathrm{~g}$ $\mathrm{NaCl} / \mathrm{kg}$ of the soil $\left(\mathrm{S}_{\mathrm{s}}\right), 10 \mathrm{~g} \mathrm{NaCl} / \mathrm{kg}$ of the soil $\left(\mathrm{S}_{6}\right), 12 \mathrm{~g} \mathrm{NaCl} / \mathrm{kg}$ of the soil $\left(\mathrm{S}_{7}\right)$ and $14 \mathrm{~g} \mathrm{NaCl} / \mathrm{kg}$ of the soil $\left.\left(\mathrm{S}_{\mathrm{s}}\right)\right)$. After 6 months of the treatment, the following results were obtained:

\section{Survival of plants}

Survival of nodulated plants decreased to $40 \%$ at $S_{7}$, while the unnodulated ones showed the same trend, but at $S_{6}$. However, from $S_{3}$ up to $\mathrm{S}_{8}$ salinity levels, the nodulated plants showed survival significantly higher than that displayed unnodulated ones (Table 2).

\section{Shoot growth rate (SGR)}

As the concentration of $\mathrm{NaCl}$ was progressively increased, SGR of plants was reduced, but the rate of such reduction was lower in nodulated plants than in unnodulated ones, particularly at the high levels of salinity (from $\mathrm{S}_{4}$ up to $\mathrm{S}_{8}$ treatments) (Table 2).

\section{Dry matter of plants}

Shoot, root and total dry matter of nodulated plants were significantly higher than those of unnodulated ones at similar levels of salinity. Total dry matter (TDM) of nodulated plants was more than 3 and 4 times than that of unnodulated ones at $S_{1}$ and $S_{8}$, respectively. It is found also that the TDM in nodulated plants was progressively increased as the salinity level increased up to $S_{5}$ treatment then progressively decreased to the lowest level at $S_{8}-$ treatment (Table 2). These findings are in agreement with those found by Kurdali and Al-Ain (2002), since they found that $\% \mathrm{~N}_{2}$ fixation was significantly enhanced by a moderate salinity level $\left(E C_{w}\right.$ of $\left.4.03 \mathrm{dS} / \mathrm{m}\right)$ in irrigated water, whereas little effects were obtained with higher water salinity levels (up to $12.3 \mathrm{dS} / \mathrm{m}$ ).

Nodule dry matter (NDM)

Statistical analysis of the data revealed that the NDM (only in nodulated plants) was not significantly affected by salinity stress up to $S_{6}$. However, NDM was decreased by about $50 \%$ at $S_{7}$ and $S_{8}$ treatments (Table 2). 
J. Agric. Sci. Mansoura Univ., 34 (6), June, 2009

T2 
These results obtained in the experiment (I) indicated that the survival, growth rate and total dry matter of nodulated plants were decreased at high salinity level $\left(\mathrm{S}_{7}\right)$. In addition, the nodules showed significant reduction in their growth at the same level of salinity. These results agree with those obtained by El-Settawy and El-Gamal (2003).

\section{Experiment (2) \\ Survival of plants}

Survival after 6 months of the treatments with $600 \mathrm{mM}$ of $\mathrm{NaCl}$ of nodulated and uninoculated Casuarina glauca plants showed that seedlings were significantly affected by nodulation induced by the Frankia and salinity stress. However survival of uninoculated salinized roots (S) showed the lowest survival levels, $30 \%$ for the first season and $20 \%$ for the second one, as compared with the control, nodulated plants (F), plants whose nodules directly exposed to salinized rhizosphere (FIS) and those indirectly exposed to salinity stress (FOS). However FIS treated plants showed survival level of $100 \%$ for both seasons, while FOS treated plants showed 100 and $90 \%$ in the first and second seasons, respectively (Tables 3 and 4). On the other hand, studies showed that other leguminous trees, e.g., Leucaena leucocephala and Tamarindus indica can't survive at $0.6 \%$ of $\mathrm{NaCl}$ (Panchban et al., 1989).

\section{Life shoot ratio (LSR)}

The symptoms of salinity affected plants were observed 2 weeks after transplanting of plants to salinized soil. These symptoms included dieback and browning of the branchlet tips. One month after treatment, branchlet cast symptoms took place. Nodulated plants showed such symptoms as they resumed their growth by inducing new branchlets from the lower part of the stem (Fig. 2), while the unnodulated ones failed to initiate it. LSR of S-treated plants was significantly decreased to the lowest levels (10 and $5 \%$ for first and second season, respectively). Meanwhile, FIS plants showed LSR of 85 and $100 \%$ for the first and second season, respectively; but they showed no significant differences as compared with that obtained in FOS ones, except for second season (Tables 3 and 4). This could be done to that the salt is accumulated in branchlets of nodulated plants. Such branchlets detached then compensated with new branchlets presumably by the action of noduleinducing hormones. Silver et al (1966) and Dullaart (1970) detected some hormones in nodules induced by Frankia, such as IAA, which is strongly involved in enlargement and multiplication of nodule cells.

\section{Increase rate of nodule diameter (IND)}

IND was significantly affected by salinity stress. However, IND of $F$ plants (unsalinized nodules) was significantly higher than that of FIS- and FOS- ones. In the second season, however, there were no significant differences between F and FOS ones (Tables 3 and 4). This indicates that the direct exposure of nodule to salinity stress hindered nodule growth, while the indirect exposure of root to salinity brought about negligible effects. Salehi et al. (2008) found that the number of active nodules and nitrogen content decreased significantly with increasing salinity of Medicago sativa L. 


\section{Nodule dry weight (ND W)}

Nodule dry weights of unsalinized roots $(F)$ and directly salinized ones (FIS) were not significantly different, but both were higher than that of indirectly salinized ones (FOS). These results point out that Frankia might tolerate $\mathrm{NaCl}$ in the rhizosphere. It seems also that Frankia may possess halophytic nature, since NDW of FIS plants was higher than that of FOStreated ones (Table 3 and 4).

\section{Relative weight of nodule (RWN)}

RWN was significantly decreased due to direct exposure of the nodule to salinity (in FIS plants). On the other hand, there was no significant difference between FOS and $\mathrm{F}$ plants in RWN. These results indicated that Frankia enhances root growth of its partner whenever subjected to salinity stress to a rate higher than that at normal conditions, since there was no significant difference between F and FIS plants in nodule dry matter (Tables 3 and 4).

\section{Growth rate of shoots (GRS)}

The GRS of nodulated plants (FIS, FOS) was higher than that of unnodulated ones under salinity stress. On the other hand, GRS of nodulated plant $(F)$ was significantly higher than that of unnodulated one (control) under normal (unsalinized) conditions. However, in both seasons, GRS of FIS plants were higher than that of FOS ones, but the later showed GRS significantly higher than that of unnodulated ones (S) (Tables 3 and 4). However, F plants showed the highest GRS followed, by the control and FIS ones for the first season. Also, there was no significant difference between control and FIS plants in the first season. On the other hand, in the second season, FIS plants showed GRS significantly higher than that of control. These results indicated that the incidence of nodules led to minimize the detrimental effect of salinity stress on growth rate of shoots. Shoot growth rates of FIS and FOS plants were about 8 and 4 times higher than that of unnodulated plants and (S plants), respectively.

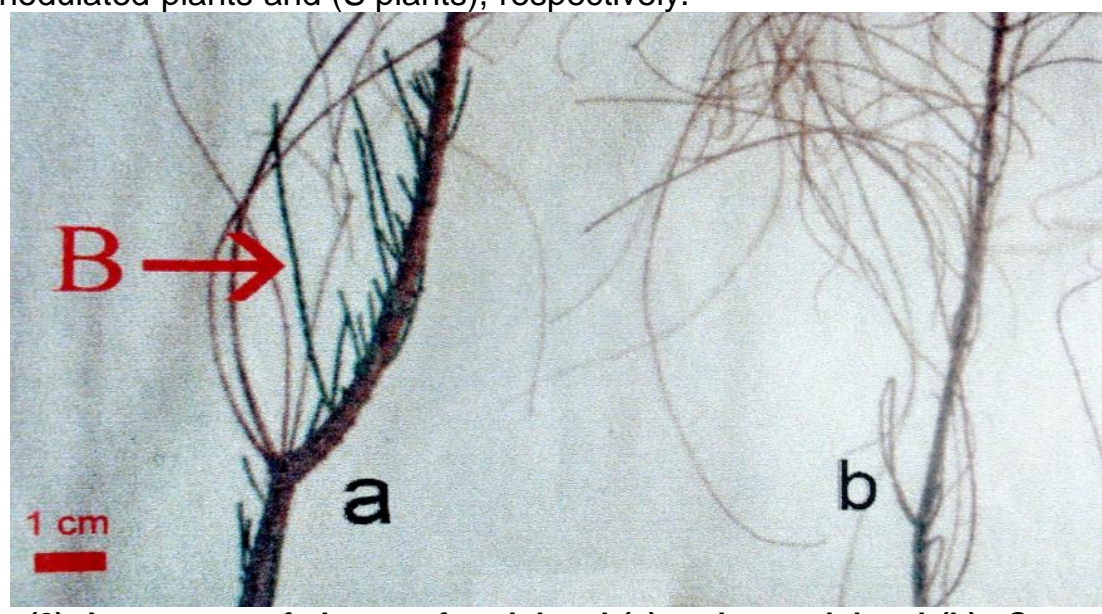

Fig. (2): Lower part of shoots of nodulated (a) and unnodulated (b) Casuarina glauca seedlings after one month of salinization treatment. B is a newly formed branchlet, induced only in nodulated plant. 
Table 3: Survival, life shoot ratio, increase rate of nodule diameter (IRND), shoot growth rate (SGR), stem diameter, branchlet and root dry weight, dry weight of nodule of unnodulated and nodulated plants under normal and salinity conditions.

\begin{tabular}{|l|c|c|c|c|c|}
\hline \multicolumn{1}{|c|}{ Paramater } & Cont. & F & FIS & FOS & S \\
\hline Survival (\%) & $90.00^{\mathrm{a}}$ & $100.00^{\mathrm{a}}$ & $100.00^{\mathrm{a}}$ & $100.00^{\mathrm{a}}$ & $30.00^{\mathrm{b}}$ \\
\hline Life shoot ratio & $100.00^{\mathrm{a}}$ & $100.00^{\mathrm{a}}$ & $85.00^{\mathrm{a}}$ & $90.00^{\mathrm{a}}$ & $10.00^{\mathrm{b}}$ \\
\hline IRND (cm/month) & - & $0.21^{\mathrm{b}}$ & $0.06^{\mathrm{a}}$ & $0.16^{\mathrm{a}}$ & - \\
\hline Nodule dry weight (gm) & - & $0.39^{\mathrm{a}}$ & $0.37^{\mathrm{a}}$ & $0.284^{\mathrm{b}}$ & - \\
\hline Relative nodule weight & - & $0.31^{\mathrm{a}}$ & $0.27^{\mathrm{a}}$ & $0.12^{\mathrm{b}}$ & - \\
\hline SGR (cm/month) & $4.10^{\mathrm{b}}$ & $5.28^{\mathrm{a}}$ & $3.95^{\mathrm{b}}$ & $1.00^{\mathrm{c}}$ & $0.25^{\mathrm{d}}$ \\
\hline Stem diameter (cm) & $0.25^{\mathrm{b}}$ & $0.42^{\mathrm{a}}$ & $0.40^{\mathrm{a}}$ & $0.20^{\mathrm{b}}$ & $0.20^{\mathrm{b}}$ \\
\hline Stem dry matter (g) & $0.83^{\mathrm{bc}}$ & $1.86^{\mathrm{b}}$ & $3.40^{\mathrm{a}}$ & $0.84^{\mathrm{c}}$ & $0.55^{\mathrm{d}}$ \\
\hline Branchlet dry matter (g) & $1.00^{\mathrm{bc}}$ & $1.09^{\mathrm{b}}$ & $3.44^{\mathrm{a}}$ & $0.87^{\mathrm{c}}$ & $0.50^{\mathrm{a}}$ \\
\hline Root dry matter (g) & $0.59^{\mathrm{d}}$ & $1.77^{\mathrm{b}}$ & $3.70^{\mathrm{a}}$ & $1.24^{\mathrm{c}}$ & $0.136^{\mathrm{e}}$ \\
\hline Total dry matter (g) & $2.42^{\mathrm{c}}$ & $4.72^{\mathrm{b}}$ & $10.54^{\mathrm{a}}$ & $2.95^{\mathrm{c}}$ & $1.86^{\mathrm{d}}$ \\
\hline Shoot/root ratio & $3.10^{\mathrm{b}}$ & $1.66^{\mathrm{cd}}$ & $1.80^{\mathrm{c}}$ & $1.37^{\mathrm{d}}$ & $8.07^{\mathrm{a}}$ \\
\hline
\end{tabular}

For each row, the values of the same postscript are not significantly different at 0.05 of probability level according to LSD multiple ranges.

Table 4: Survival, life shoot ratio, increase rate of nodule diameter (IRND), shoot growth rate (SGR), stem diameter, branchlet and root dry weight, dry weight of nodule of unnodulated and nondulated plants under normal and salinity conditions.

\begin{tabular}{|l|c|c|c|c|c|}
\hline Parameter & Cont. & F & FIS & FOS & S \\
\hline Survival (\%) & $100.00^{\mathrm{a}}$ & $100.00^{\mathrm{a}}$ & $100.00^{\mathrm{a}}$ & $100.00^{\mathrm{a}}$ & $20.00^{\mathrm{b}}$ \\
\hline Life shoot ratio (\%) & $90.00^{\mathrm{b}}$ & $100.00^{\mathrm{a}}$ & $100.00^{\mathrm{a}}$ & $90.00^{\mathrm{b}}$ & $5.00^{\mathrm{c}}$ \\
\hline $\begin{array}{l}\text { Increase rate of nodule diam. } \\
\text { (cm/month) }\end{array}$ & - & $0.14^{\mathrm{a}}$ & $0.07 \mathrm{~b}$ & $0.17 \mathrm{a}$ & - \\
\hline Nodule dry weight (gm) & - & $0.42^{\mathrm{a}}$ & $0.40^{\mathrm{a}}$ & $0.21^{\mathrm{b}}$ & - \\
\hline Relative nodule weight & - & $0.20^{\mathrm{a}}$ & $0.11^{\mathrm{b}}$ & $0.19^{\mathrm{a}}$ & - \\
\hline Shoot growth rate (cm/month) & $4.00^{\mathrm{b}}$ & $6.43^{\mathrm{a}}$ & $5.70^{\mathrm{a}}$ & $1.09^{\mathrm{c}}$ & $0.03^{\mathrm{d}}$ \\
\hline Stem diameter (cm) & $0.30^{\mathrm{b}}$ & $0.39^{\mathrm{a}}$ & $0.40^{\mathrm{a}}$ & $0.20^{\mathrm{b}}$ & $0.20^{\mathrm{b}}$ \\
\hline Stem dry matter (g) & $90.0^{\mathrm{b}}$ & $0.02^{\mathrm{a}}$ & $3.30^{\mathrm{a}}$ & $0.69^{\mathrm{b}}$ & $0.50^{\mathrm{c}}$ \\
\hline Branchlet dry matter (g) & $1.30^{\mathrm{c}}$ & $2.01^{\mathrm{b}}$ & $4.14^{\mathrm{a}}$ & $0.90^{\mathrm{d}}$ & $0.52^{\mathrm{a}}$ \\
Root dry matter (g) & $0.59^{\mathrm{d}}$ & $2.08^{\mathrm{b}}$ & $3.62^{\mathrm{a}}$ & $1.10^{\mathrm{c}}$ & $0.20^{\mathrm{e}}$ \\
Total dry matter (g) & $3.79^{\mathrm{c}}$ & $6.20^{\mathrm{b}}$ & $10.06^{\mathrm{a}}$ & $2.69^{\mathrm{d}}$ & $1.22^{\mathrm{e}}$ \\
\hline Shoot/root ratio & $3.70^{\mathrm{b}}$ & $1.98^{\mathrm{c}}$ & $2.00^{\mathrm{c}}$ & $1.44^{\mathrm{d}}$ & $5.10^{\mathrm{a}}$ \\
\hline
\end{tabular}

For each row, the values of the same postscript are not significantly different at 0.05 of probability level according to LSD multiple ranges.

\section{Stem diameter}

Stem diameter of nodulated plants, either under salinity stress (particularly FIS) of normal condition, was significantly higher than that of unnodulated ones in both seasons. However, stem diameter of FIS plants was significantly higher than that of FOS ones (Tables 3 and 4). Statistical analysis of variance revealed that there was no significant difference between F and FIS plants with respect to stem diameter. Thus, direct exposure of nodulated root had no effect on stem diameter. 


\section{Dry matter of plants}

Statistical analysis of variance revealed that the FIS plants had significantly dry matter of stem, branchlet and root than those of the other treatments, even those unsalinized and nodulated ones $(F)$. Unnodulated plants under salinized condition (S) showed the lowest dry matter of stem, branchlets and root for both the two seasons (Tables 3 and 4). As for total dry matter, FIS plants were 4.3, 1.9, 3.5, and 5.6 times higher than those of $F$, FOS, control and $S$ ones in the first season and were 2.6, 1.6, 3.1 and 8.2 times higher in the second one; respectively.

\section{Shoot/ Root Ratio}

Shoot/ root ratio of plant was significantly affected by nodulation and/or salinity stress. Plants of unnodulated root displayed shoot/root ratio significantly higher than that of nodulated ones either under normal (unsalinized) or stressed (salinized) conditions. This decrease is ascribed to the relative increase of dry weight of root system rather than in shoots of nodulated plants as compared with unnodulated ones. The high shoot/root ratio of unnodulated plants is attributed to the decrease in growth of root system as a result of direct effect of salinity stress. These results prove the positive effect of nodules in minimizing the hazardous effects of salinity stress particularly in FIS plants,

\section{Mineral contents of branchlets}

Branchlets of nodulated plants contained higher $\mathrm{N}$ concentration than those of unnodulated ones in both seasons. Only in nodulated plants, salinity stress has reduced $\mathrm{N}$ content of branchlets (Tables 4 and 5 ) relative to that obtained in unsalinized ones $(F)$. It was also found that there were no significant differences in $\mathrm{N}$ content between FIS and FOS plants. These results may suggest that the translocation of $\mathrm{N}$ was hindered owing to direct and indirect exposure of nodulated root to salinized rhizosphere. As for the unnodulated plants, there were no significant differences in $\mathrm{N}$ content of branchlets between the control plants and the salinized ones (S). Studies showed that the reduction of $\mathrm{N}$ content in shoots of Prosopis juliflora was decreased with the increase in salinity (Mahmood and Mahmood, 1989 and van Hoorn et al., 2001.). Gauch and Wadleight (1962) attributed the reduction in $\mathrm{N}$ contents to depression of $\mathrm{Na}$ uptake. Deane-Drummond and Glass (1982) found that $\mathrm{Cl}^{-}$inhibits $\mathrm{NO}_{3}{ }^{-}$uptake. The reduction of $\mathrm{N}$ contents in shoots, in many cases, did not affect carbohydrate accumulation. Since there is evidences that the carbohydrates had accumulated in shoots after exposure to salinity (Munns and Termaat, 1986 and Al-Sobhi et al, 2006), particularly in salinity tolerant plants (Almodares et al, 2008).

Phosphorus content was decreased in branchlets owing to the effect of salinity except for FOS-treated plants for both seasons. Phosphorus content under normal conditions was not affected by incidence of nodules in the root (Tables 5 and 6). Similar results were obtained in Populus alba (Munoz et al., 1996). Ashour et al. (1970) ascribed the reduction of phosphorus content in shoots to the increase in $\mathrm{pH}$ and possibly $\mathrm{Cl}^{-}$suppressing $\mathrm{P}$ uptake into plant (Papadopoulos and Rendig, 1983). 
Table 5: Nitrogen, $\mathrm{P}, \mathrm{K}$ and $\mathrm{Na}$ contents of branchlets and roots of unnodulated $C$. glauca plants (cont.), nodulated plants (F), FIS,FOS- and S treated plants in the first season.

\begin{tabular}{|l|c|c|c|c|c|c|}
\hline \multicolumn{7}{|c|}{ Treatments } \\
\hline Plant organ & Element (\%) & Cont & F & FIS & FOS & S \\
\hline \multirow{4}{*}{ Branchlets } & $\mathrm{N}$ & $1.100^{\mathrm{c}}$ & $2.320^{\mathrm{a}}$ & $1.340^{\mathrm{b}}$ & $1.300^{\mathrm{b}}$ & $1.050^{\mathrm{c}}$ \\
& $\mathrm{P}$ & $0.220^{\mathrm{a}}$ & $0.320^{\mathrm{a}}$ & $0.125^{\mathrm{c}}$ & $0.200^{\mathrm{ab}}$ & $0.175^{\mathrm{b}}$ \\
& $\mathrm{K}$ & $0.680^{\mathrm{c}}$ & $0.920^{\mathrm{b}}$ & $1.080^{\mathrm{a}}$ & $1.100^{\mathrm{a}}$ & $0.500^{\mathrm{d}}$ \\
& $\mathrm{Na}$ & $0.325^{\mathrm{c}}$ & $0.350^{\mathrm{c}}$ & $0.370^{\mathrm{c}}$ & $0.800^{\mathrm{b}}$ & $1.820^{\mathrm{a}}$ \\
\hline \multirow{3}{*}{ Roots } & $\mathrm{N}$ & $0.520^{\mathrm{d}}$ & $0.740^{\mathrm{b}}$ & $0.840^{\mathrm{a}}$ & $0.860^{\mathrm{a}}$ & $0.650^{\mathrm{c}}$ \\
& $\mathrm{P}$ & $0.150^{\mathrm{d}}$ & $0.400^{\mathrm{a}}$ & $0.265^{\mathrm{c}}$ & $0.266^{\mathrm{c}}$ & $0.280^{\mathrm{b}}$ \\
& $\mathrm{K}$ & $0.290^{\mathrm{c}}$ & $0.500^{\mathrm{b}}$ & $0.170^{\mathrm{d}}$ & $1.200^{\mathrm{a}}$ & $0.188^{\mathrm{d}}$ \\
& $\mathrm{Na}$ & $0.225^{\mathrm{b}}$ & $0.140^{\mathrm{c}}$ & $0.165^{\mathrm{c}}$ & $0.200^{\mathrm{b}}$ & $0.630^{\mathrm{a}}$ \\
\hline
\end{tabular}

The values (for each row) of the same postscript are not significantly different at 0.05 of probability level according to LSD multiple ranges.

Table 6: Nitrogen, $\mathrm{P}, \mathrm{K}$ and $\mathrm{Na}$ contents of branchlets and roots of unnodulated C. glauca Plants (cont.), nodulated plants (F), FIS-, FOS- and S- treated plants in the second season.

\begin{tabular}{|l|l|l|l|l|l|l|}
\hline \multicolumn{7}{|l|}{ Treatments } \\
\hline Plant organ & Element(\%) & Cont & F & FIS & FOS & S \\
\hline \multirow{4}{*}{ Branchlets } & $\mathrm{N}$ & $1.050^{\mathrm{c}}$ & $2.150^{\mathrm{a}}$ & $1.380^{\mathrm{b}}$ & $1.380^{\mathrm{b}}$ & $1.050^{\mathrm{c}}$ \\
& $\mathrm{P}$ & $0.200^{\mathrm{a}}$ & $0.220^{\mathrm{a}}$ & $0.135^{\mathrm{b}}$ & $0.215^{\mathrm{a}}$ & $0.150^{\mathrm{b}}$ \\
& $\mathrm{K}$ & $0.800^{\mathrm{b}}$ & $0.890^{\mathrm{b}}$ & $1.100^{\mathrm{a}}$ & $1.100^{\mathrm{a}}$ & $0.465^{\mathrm{c}}$ \\
& $\mathrm{Na}$ & $0.420^{\mathrm{c}}$ & $0.330^{\mathrm{d}}$ & $0.355^{\mathrm{d}}$ & $0.830^{\mathrm{b}}$ & $1.670^{\mathrm{a}}$ \\
\hline \multirow{5}{*}{ Roots } & $\mathrm{N}$ & $0.440^{\mathrm{c}}$ & $0.740^{\mathrm{a}}$ & $0.640^{\mathrm{b}}$ & $0.860^{\mathrm{a}}$ & $0.620^{\mathrm{b}}$ \\
& $\mathrm{P}$ & $0.162^{\mathrm{c}}$ & $0.330^{\mathrm{a}}$ & $0.296^{\mathrm{b}}$ & $0.296^{\mathrm{b}}$ & $0.325^{\mathrm{a}}$ \\
& $\mathrm{K}$ & $0.307^{\mathrm{c}}$ & $0.450^{\mathrm{b}}$ & $1.140^{\mathrm{a}}$ & $1.140^{\mathrm{a}}$ & $0.176^{\mathrm{d}}$ \\
& $\mathrm{Na}$ & $0.230^{\mathrm{b}}$ & $0.145^{\mathrm{c}}$ & $0.200^{\mathrm{b}}$ & $0.200^{\mathrm{b}}$ & $0.550^{\mathrm{a}}$ \\
\hline
\end{tabular}

The values (for each row) of the same postscript are not significantly different at 0.05 probability level according to LSD multiple ranges.

Potassium content in branchlets was significantly increased in FISand FOS treated plants as compared to those of the control, f-and S-treated ones. These results are not in agreement with that obtained by Walker (1989) and TieHe and Cramer (1993). This discrepancy may be attributed to the incidence of nitrogen fixing nodules of the used plants, since $S$ plants showed the lowest $\mathrm{K}$ content. However, all nodulated plants had $\mathrm{K}$ content significantly higher than those obtained in unnodulated ones (Tables 5 and 6). Hence, the nodulation via Frankia, aids plants to absorb $\mathrm{K}$ either under a direct or an indirect exposure of their roots to salinized rhizosphere.

Sodium content was increased in unnodulated plants which exposed to salinity stress (S plants) in both seasons, while nodulated ones showed decrease in $\mathrm{Na}$ content. The data set out in Tables (5 and 6) illustrated that the FIS plants had Na content lower than that of FOS ones. The greater salt tolerance of other nitrogen-fixing trees as Acacia ampliceps was associated with relatively low shoot $\mathrm{Na}$ concentration (Marcar et al., 1991). This result may prove that the nodules may regulate the pathway of $\mathrm{Na}$ in plant organs relative to that did by unnodulated root. The biofixation of gaseous nitrogen via nodulated root of the plant and its rhizosphere resembles to certain extent 
to an amendment of $\mathrm{N}$ fertilizers. El-Siddig and Ludder (1994) found that application of nitrate fertilizer decreased foliar concentration of $\mathrm{Na}$. Furthermore, plant mortality decreased as the trees fertilized with $\mathrm{N}$ element in some trees as Betula sp, Tilia sp and Ulmus sp (Dragested, 1990). The importance of $\mathrm{N}$ in this respect might be confined in the assimilation of the amino acid; proline. Proline acts as an osmoregulator agent (Watad et al., 1983 and Abd-El-Kareem, 1997) and its concentration either in shoots or roots of tolerant plants was higher than that of non-tolerant ones (Abd EI Samad and Barakat, 1999) and under salinity stress, may reach 200 fold its normal concentration in plant organs (Hartzendorf and Rolletschek. 2001).

\section{Mineral contents in roots}

Nitrogen content was significantly increased in roots of nodulated plants relative to that in unnodulated ones either under salinized soil or normal conditions. In the first season, $\mathrm{N}$ content in roots of FOS- treated plants was higher than that obtained in roots of FIS treated ones, but in the second season, there were no significant differences between each other. Nonetheless, these results showed that $\mathrm{N}$ contents of salinized root are comparable with those obtained in unnodulated plants under normal condition (control). These results suggested that Frankia was not significantly affected by salinity stress, but the translocation of $\mathrm{N}$ element via stream was affected.

Phosphorus content in the roots was affected by both salinity and formation of nodules in roots. However, under unsalinized condition, the accumulation of $P$ in nodulated roots $(F)$ was significantly higher than that of unnodulated ones, since it was more than 2 fold that found in control. On the other hand, accumulation of $\mathrm{P}$ as in nodulated roots under salinity stress was significantly decreased compared with that found in unnodulated ones ( $S$ plants). This reduction in $\mathrm{P}$ content in nodulated roots may be ascribed to the translocation of $\mathrm{P}$ element to other plant organs, such as, branchlets due to the stimulating action of Frankia.

Potassium content of roots was significantly increased in nodulated roots than unnodulated ones. The highest $\mathrm{K}$ level was obtained in roots of FOS plants in the first and second seasons, whilst the F-and FIS ones showed the lowest level. These findings may indicate that the accumulation of $\mathrm{K}$ in nodulated roots would be decreased when they were directly exposed to salinized rhizosphere owing to upward translocation of such nutrient to the branchlets (Tables 5 and 6). This active translocation of $\mathrm{K}$ is attributed to incidence of nodules, since the branchlets of S-treated plants had the lowest $\mathrm{K}$ content (Tables 5 and 6 ).

As for $\mathrm{Na}$ content in the roots, the highest content was found in $\mathrm{S}$ plants, while the lowest content was found in both of $F$ and FIS plants. These results, however, prove to great extent that the nodules induced by Frankia had controlled the accumulation of $\mathrm{Na}$ in root to least level, i.e. decreased the effect of lethal concentration of $\mathrm{Na}$ element. The decrease of some nutrient elements due to salinization was reported in several researches. Dwived et al. (1996) found that the N,P,K and Ca contents of Tamarindus indica leaves were decreased with increasing salinity. In the same tree species, Pongskul et al. (1988) found, however, that with increasing salinity, N, Na and $\mathrm{Ca}$ contents in leaves were progressively increased. 


\section{Rhizosphere properties}

The electric conductivity $(\mathrm{EC})$ of the rhizosphere was increased as a result of $\mathrm{NaCl}$ application. The highest $\mathrm{EC}$ was obtained in rhizosphere of $\mathrm{S}$ and FOS plants in both seasons (Table 7). On the other hand, EC of rhizosphere of FIS plants was significantly decreased as compared with the other treatments (FOS and S). Figure (3) indicates that in case of FIS plants, there was no difference between rhizosphere of the main and sub container in EC value, whilst sub containers of FOS and $S$ ones showed EC higher than that detected in the main one. It can be suggested that the incidence of nodules in sub container of FIS plants is responsible for the remediation of EC rhizosphere, i.e., it creates an equilibrium status of EC between rhizosphere of the main- and sub container of FOS and S plants. Due to the absence of nodule in sub-container rhizosphere, the EC value was still higher than that obtained in the main container. Sodium content of rhizosphere was significantly affected by the presence of nodules (Table 7), particularly in the second season. In both seasons, $\mathrm{Na}$ content in the rhizosphere of FIS plants was lower than that of S and FOS ones. Figure (4) showed that $\mathrm{Na}$ content was lower in the main root rhizosphere than that of subunit rhizosphere of $S$ and FOS plants, whereas in FIS ones, Na content was the same in both rhizosphere of the main and sub containers, i.e. the same trend that was obtained in EC.

Chloride content was significantly higher in FIS rhizosphere than that in FOS ones for both seasons of this study (Table 7). Figure (5) showed, however, that the subunit rhizosphere had significantly higher $\mathrm{Cl}^{-}$content than that obtained in the main root rhizosphere of FIS , FOS and S plants. This result may indicate that the incorporation and movement of $\mathrm{Cl}$ in root system or nodules is less extent at salinized condition relative to the normal one.

Nitrogen content in the rhizosphere under normal condition was higher in nodulated plants than that in unnodulated ones (Table 7). Amount of $\mathrm{N}$ in rhizosphere was affected by salinity stress, probably as the absorption of such element throughout the root system and nodules is decreased, i.e. depletion of $\mathrm{N}$ by plant. Figure (6) indicates that the $\mathrm{N}$ content was higher in the main container than that in sub one in case of FIS and S plants. However in the case of FOS, there was no difference in $\mathrm{N}$ content between that in the main container and that in sub one. Translocation of $\mathrm{N}$ element by FIS plants might be hindered due to the direct effect of salinity. By tracing $N$ content in plants (Tables 5 and 6), nodulated roots subjected to salinized condition had $\mathrm{N}$ content significantly higher than that of the other treatments compared with $\mathrm{N}$ content of branchlets. These results may interpret why $\mathrm{N}$ content is reduced in sub root rhizosphere. In FOS plants, it was found that $\mathrm{N}$ content in sub container significantly decreased to lower levels as the plant was subjected to salinity stress, possibly owing to ambient consumption of this element by the plant. This state holds true also in case of stressed plants. 


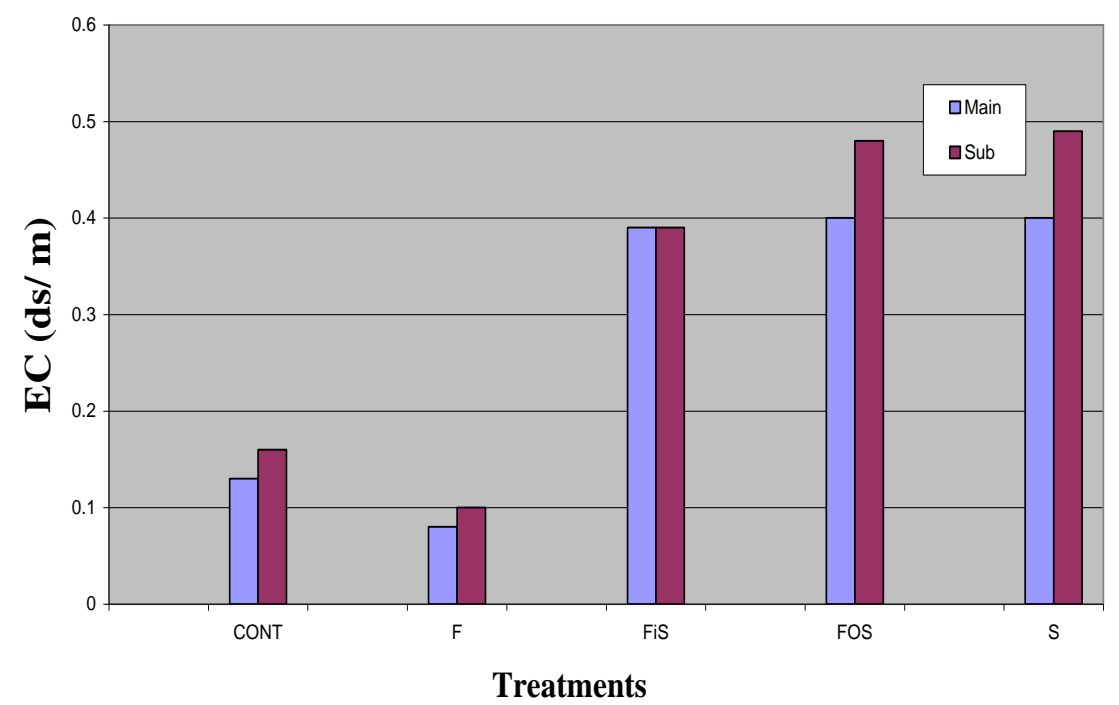

Fig .(3) : EC (ds/m)of main - and sub - container rhizosphere of control, F-, FIS-, FOS-, S- plants.

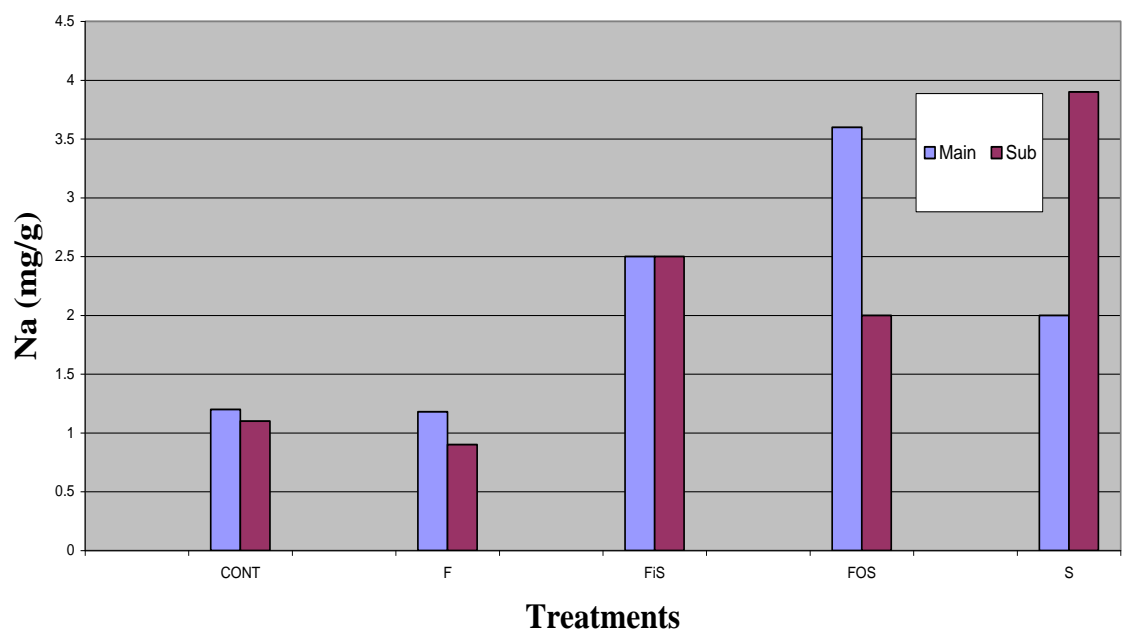

Fig .(4) : $\mathrm{Na}(\mathrm{mg} / \mathrm{g})$ of main- and sub- container rhizosphere of control, F-, FIS- ,FOS- and S- plants. 
El-Settawy, A.A. A. and Amal A. S. EL-Gamal

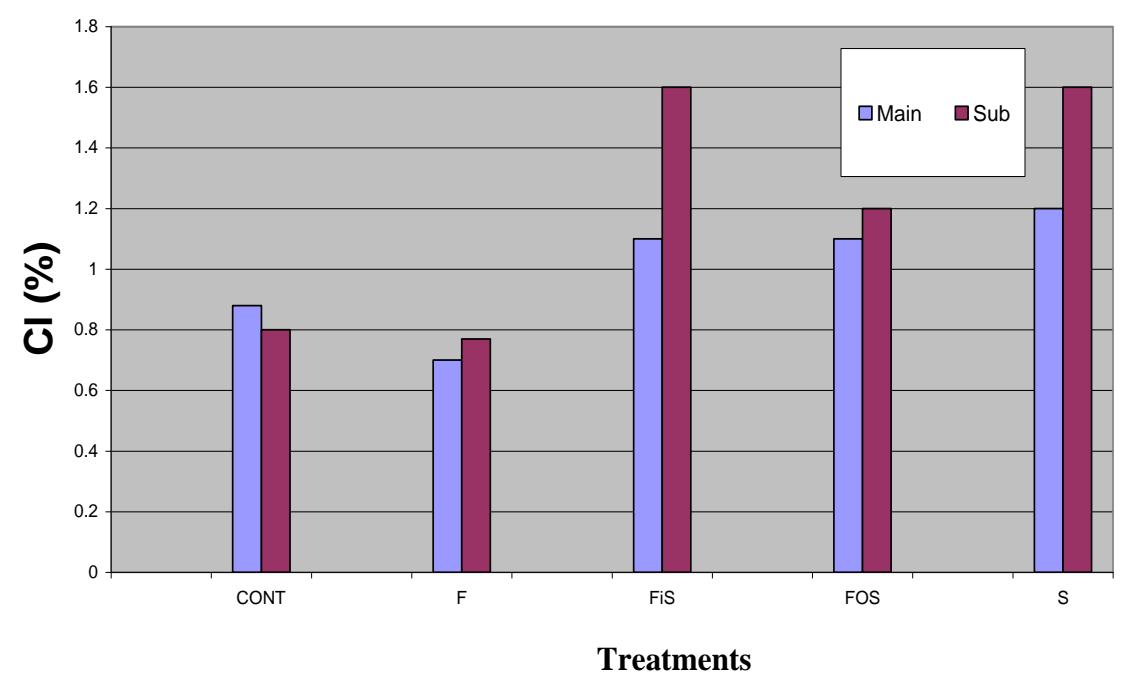

Fig .(5) : $\mathrm{Cl}(\%)$ of main - and sub - container rhizosphere of control, F-, FIS-, FOS- and S- plants.

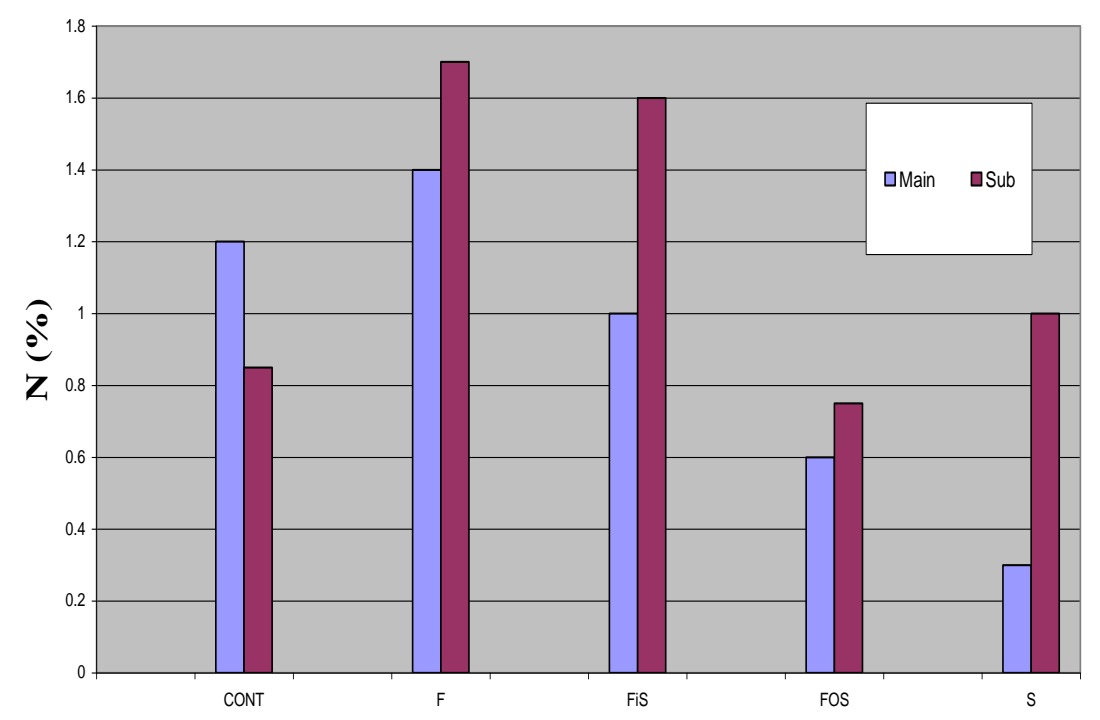

Treatments

Fig . (6) : $N(\%)$ of main - and sub - container rhizosphere of control, F-, FIS-, FOS- and S- plants. 
Table 7: EC (ds/m), $\mathrm{Na}, \mathrm{Cl}$ and total $\mathrm{N} \%$ of rhizosphere of control, nodulated root $(F)$, nodulated root exposed directly to salinity (FiS), indirectly exposed one (FOS) and unnodulated one exposed to salinity (S) for first and second seasons.

\begin{tabular}{|l|c|c|c|c|c|c|}
\hline \multicolumn{7}{|c|}{ Treatments } \\
\hline Seasons & $\begin{array}{c}\text { Rhizosphere } \\
\text { parameter }\end{array}$ & Cont. & F & FIS & FOS & S \\
\hline \multirow{3}{*}{ First } & $\mathrm{EC}(\mathrm{ds} / \mathrm{m})$ & $1.125^{\mathrm{c}}$ & $0.095^{\mathrm{c}}$ & $1.390^{\mathrm{b}}$ & $0.435^{\mathrm{a}}$ & $0.400^{\mathrm{a}}$ \\
season & $\mathrm{Na} \mathrm{( \% )}$ & $0.25^{\mathrm{d}}$ & $0.100^{\mathrm{d}}$ & $2.480^{\mathrm{c}}$ & $3.100^{\mathrm{b}}$ & $3.000^{\mathrm{a}}$ \\
& $\mathrm{Cl}(\%)$ & $0.820^{\mathrm{c}}$ & $0.790^{\mathrm{c}}$ & $1.310^{\mathrm{a}}$ & $1.160^{\mathrm{b}}$ & $1.400^{\mathrm{a}}$ \\
& $\mathrm{N}(\%)$ & $0.050^{\mathrm{b}}$ & $1.600^{\mathrm{a}}$ & $0.900^{\mathrm{c}}$ & $0.650^{\mathrm{d}}$ & $0.600^{\mathrm{d}}$ \\
\hline \multirow{3}{*}{ Second } & $\mathrm{EC} \mathrm{(ds/m)}$ & $0.440^{\mathrm{c}}$ & $0.740^{\mathrm{a}}$ & $0.395^{\mathrm{b}}$ & $0.450^{\mathrm{a}}$ & $0.470^{\mathrm{a}}$ \\
season & $\mathrm{Na} \mathrm{( \% )}$ & $0.162^{\mathrm{c}}$ & $0.330^{\mathrm{a}}$ & $0.500^{\mathrm{c}}$ & $3.150^{\mathrm{b}}$ & $3.900^{\mathrm{a}}$ \\
& $\mathrm{Cl}(\%)$ & $0.307^{\mathrm{c}}$ & $0.450^{\mathrm{b}}$ & $1.380^{\mathrm{a}}$ & $1.220^{\mathrm{b}}$ & $1.460^{\mathrm{a}}$ \\
& $\mathrm{N} \mathrm{( \% )}$ & $1.080^{\mathrm{b}}$ & $1.480^{\mathrm{a}}$ & $1.020^{\mathrm{b}}$ & $0.700^{\mathrm{c}}$ & $0.600^{\mathrm{c}}$ \\
\hline
\end{tabular}

The values (for each row) of the same postscript are not significantly different at 0.05 probability level according to LSD multiple ranges.

\section{Experiment (3)}

Relationship between nodule diameter and $\mathrm{EC}$, and $\mathrm{N}, \mathrm{Na}$ and $\mathrm{Cl}$ contents in the rhizosphere

The incidence of nodule had a positive effect on remediation of rhizosphere in situ. It was found that the higher the nodule diameter; the lower the EC, $\mathrm{Na}$ and $\mathrm{Cl}$ contents of rhizosphere (Figs. 7, 8 and 9).

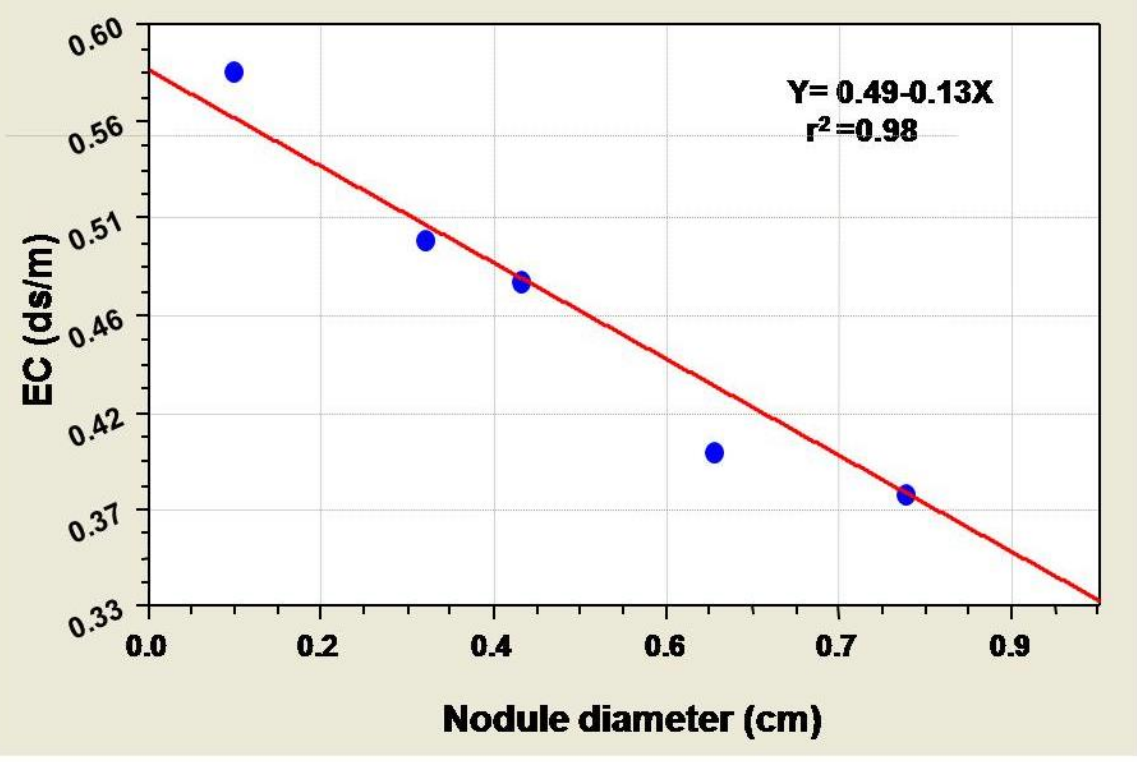

Fig (7) : Linear relationship between nodule diameter and EC value of mizosphere . 
El-Settawy, A.A. A. and Amal A. S. EL-Gamal

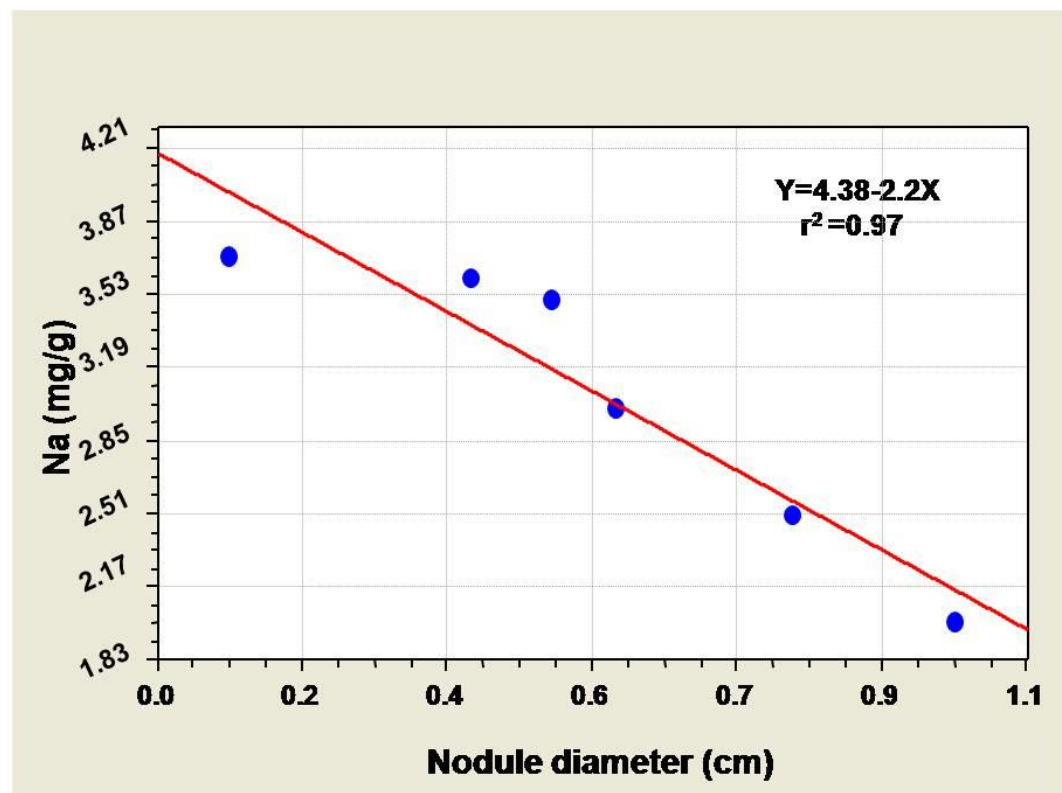

Fig (8) : Linear relationship between nodule diameter and $\mathrm{Na}$ content of mizosphere

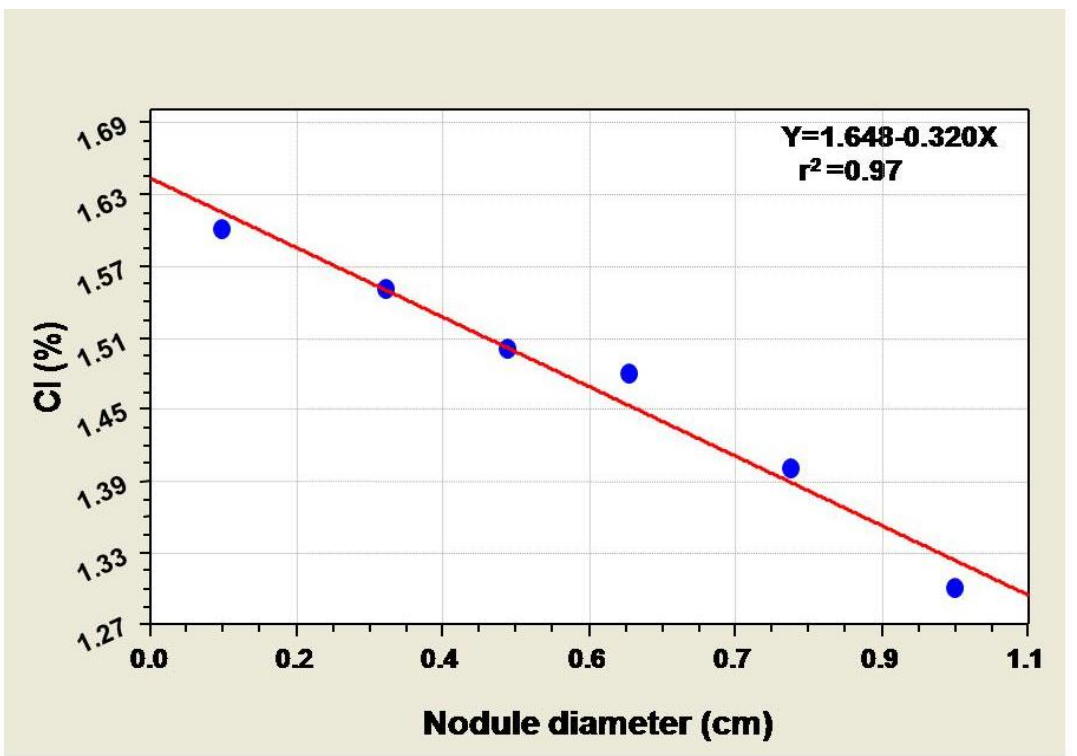

Fig (9) : Linear relationship between nodule diameter and content of $\mathrm{Cl}$ in mizosphere

On the other hand, $\mathrm{N}$ content and total dry matter of rhizosphere was directly increased with nodule diameter; i. e., the higher the nodule diameter, the higher the $\mathrm{N}$ content, root, shoot and total dry matter (Figs. 10,11, 12 and 13). The positive effect of nodule, in salinized soil, was proved by this study, 
so, it can be recommended to use nodulated roots of a large size rather than that unnodulated ones for afforestaition especially in salinized soil.

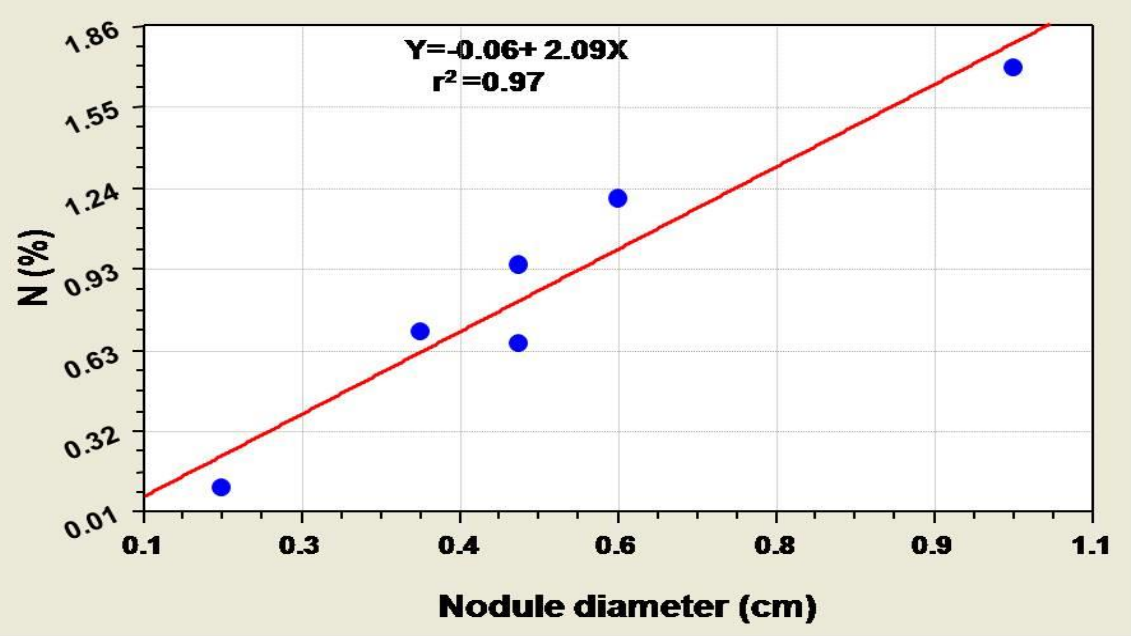

Fig (10) : Linear relationship between nodule diameter and $\mathbf{N}$ content of mizosphere .

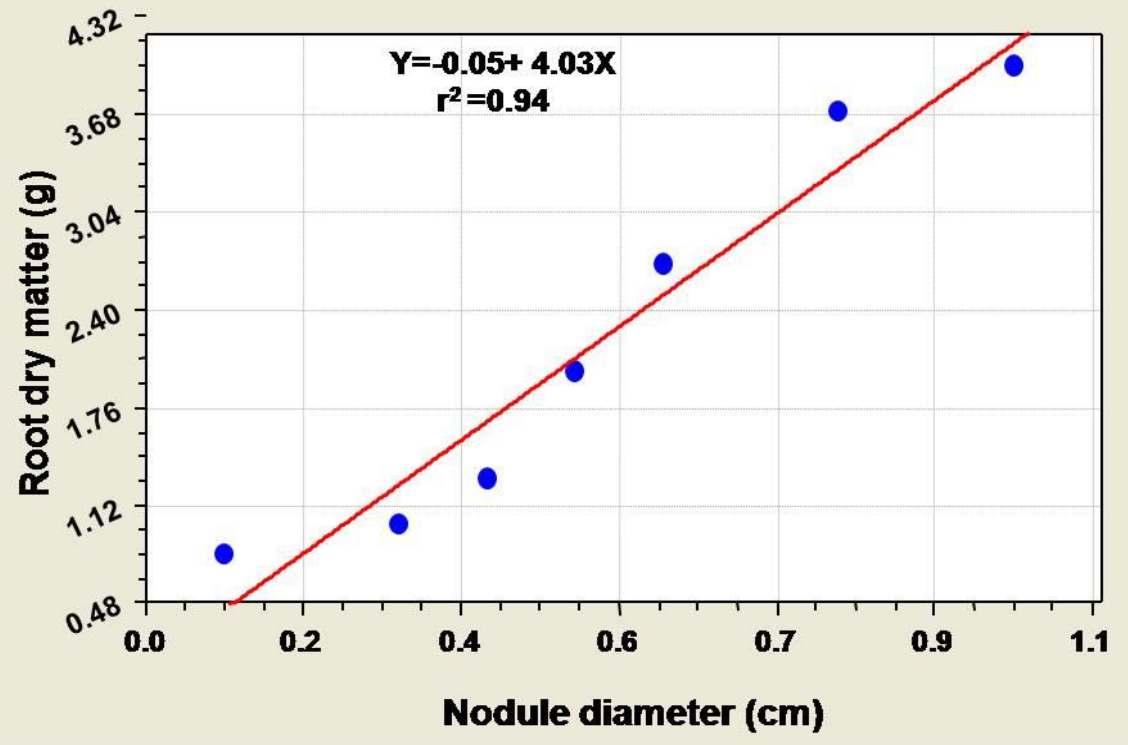

Fig. (11): Linear relationship between nodule diameter and root dry matter- 


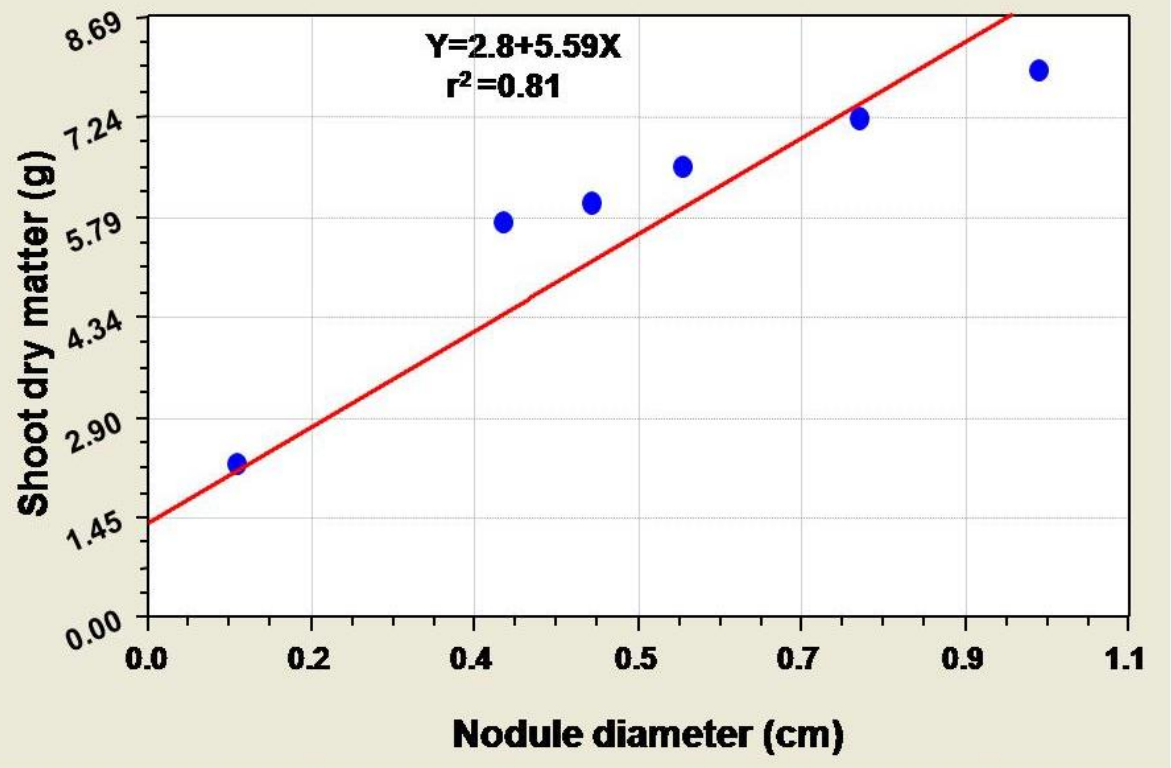

Fig. (12): Linear relationship between nodule diameter and shoot dry matter.

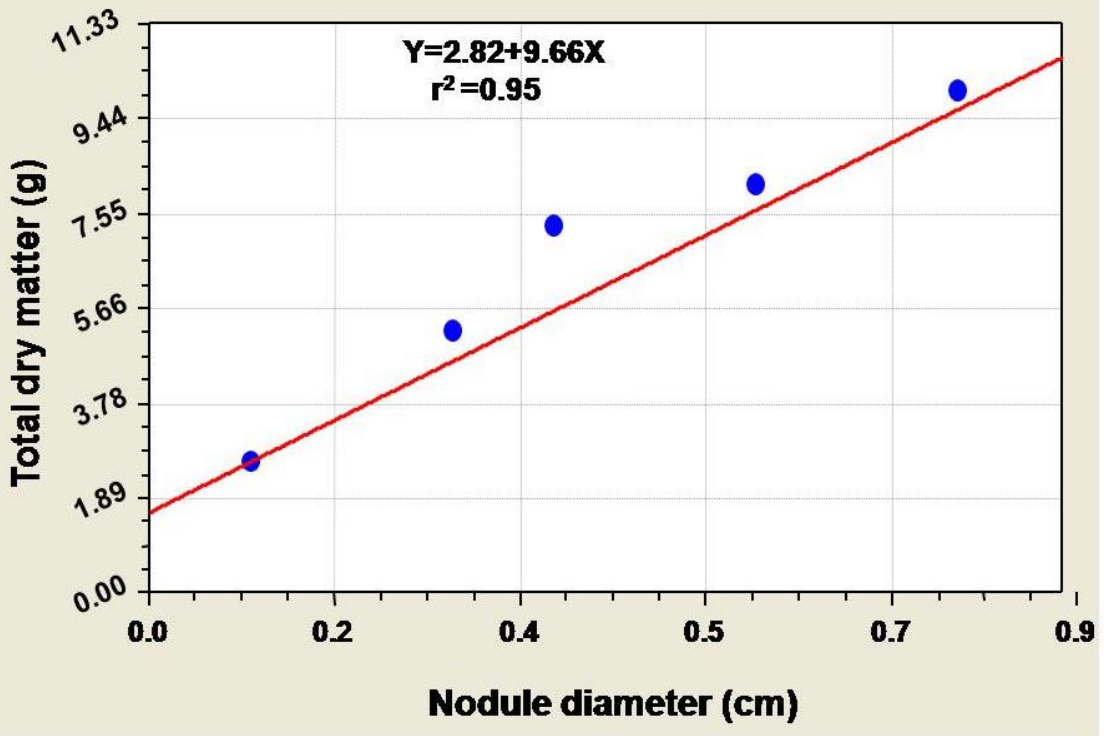

Fig. (13): Linear relationship between nodule diameter and total dry matter. 


\section{Scanning electron macrograph (SEM)}

The ultrastructure examination of nodules using SEM revealed that Frankia were affected by salinized rhizosphere, since they showed highly condensed matrix of filamentous hyphae inside the nodule cells (Fig. 14- a) as compared with that formed in normal rhizosphere (Figure 14- b) which are characterized by less dense matrix, large filamentous hyphae and large interhypha1 lumens. In addition, sporangules was collapsed with increasing salinity. It is worthy noticeable the presence of accumulated salt in cells of nodule (Figure 14- d).
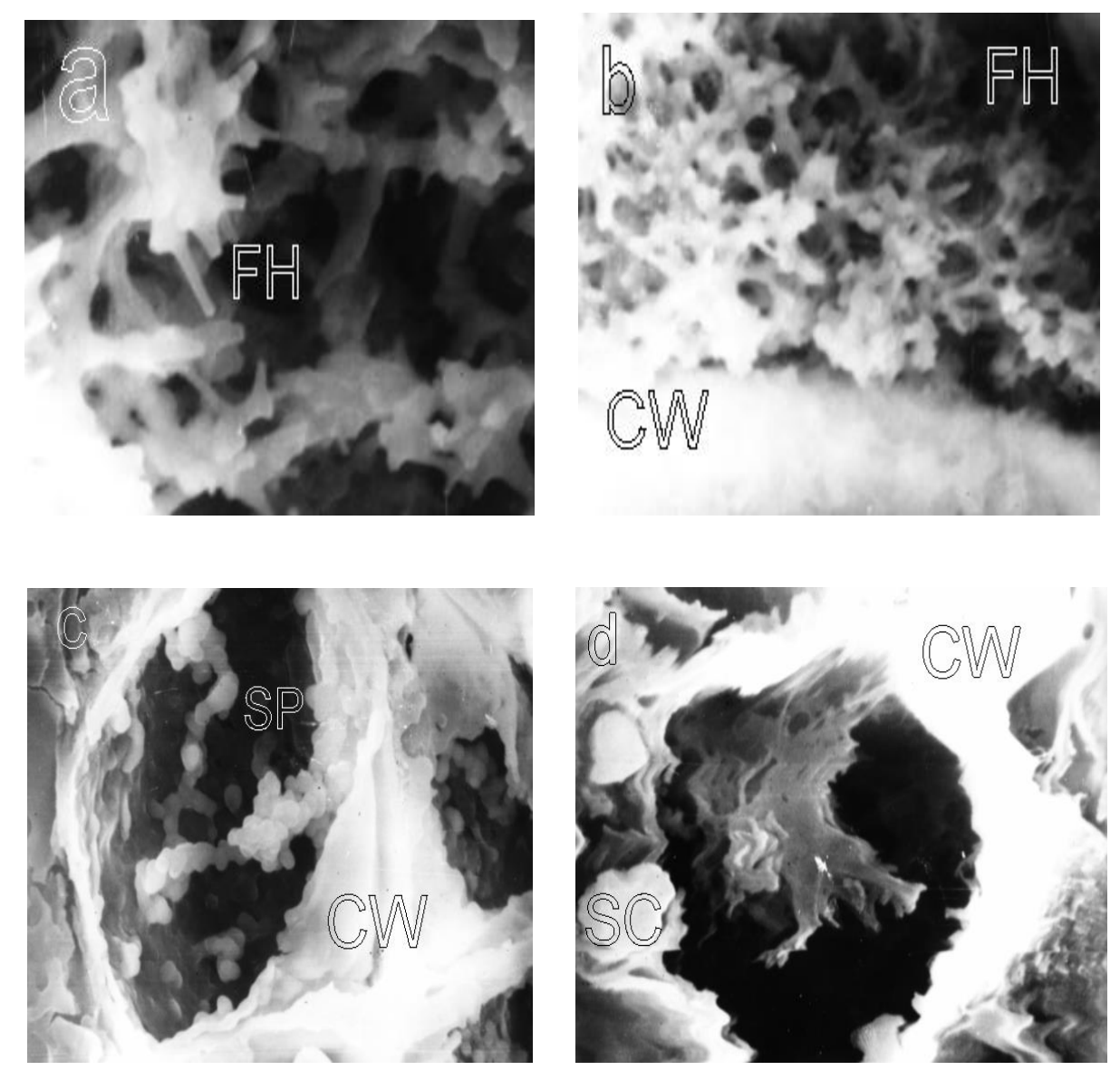

Fig. (14): Scaning electron micrographs (SEM) of nodules of Casuarina glauca: (a): Filamentous hyphae (FH) of unsalinized nodules (less dense). (b): Filamentous hyphae (FH) of salinized nodule (more dense) (c): Cell of unsalinized nodules contained sporangules (SP). (d): Salinized nodule contained salt crystals (SC). CW is the wall of nodule cell. 
These changes in the ultrastructure of Frankia furnish ambient increase in surface area of the filamentous hyphae and in turn minimized the hazardous effect of Salinity stress on nodule cells However, the complicated filamentous hyphae of Frankia that established in cortex cells of nodulated roots of $C$. glauca may possess high capability on filtration of the salts before their translocation via stream. In salinized rhizosphere, bacteria encounter relatively high osmotic conditions (Miller and Wood, 1996), Frankia however virtually can adapt with such conditions. The modification of ultrastructure may interpret why Frankia can survive in saline conditions in addition to their contribution in increasing of tolerance of their partner hosts under such salinity condition.

\section{Conclusions}

- Nodulated Casuarina glauca plants are more tolerant to salinity compared with unnodulated ones up to $12.000 \mathrm{ppm}$ of $\mathrm{NaCl}$ of salinized soil.

- Growth rate of nodules was decreased as it is subjected to salinity stress under symbiotic system, yet their dry weights were not affected by salinity.

- Ultrastructural examination revealed that the filamentous hyphae in cortex cells of nodules increased its density to adapt with salinity medium. Such modifications bring forth an increasing in surface area of hyphae, in turn remediate the salt and minimize its detrimental effect on nodule and host as well.

- Direct exposure of nodule (FIS) and indirect exposure (FOS) using split root technique revealed that Frankia are salt tolerant and can survive in salinized medium, it is enhances the salinity tolerance of its partners and the enhancement of salinity tolerance of their host is being directly (in FIStreatment) rather than their indirect effects on growth per see, since they act as filter of salt.

- The mechanisms by which Frankia induce salinity tolerance of their host presumably due to: increasing of total root area as well as volume of cortex cells that arranged in nodules.the ultrafltration of $\mathrm{Na}$ cations and regulation of its absorption via nodulated roots, biofixed nitrogen may contribute in proline induction and compensation of fallen branchlets that contained salts by inducing a formation of new branchlets.

- Afforestation with nodulated root of casuarinas is recommended in marginal lands and those relatively high in salinity. It can be recommended also afforestation with nodulated seedlings of higher number and larger size of nodules.

\section{REFERENCES}

Abd-El- Kareem, M.1997. Growth and osmoregulation of Chlorella salina and Dunaliella salina under the interaction of salinity and inorganic nitrogen source. J. Union-Arab Biol., Cairo 4(B):85-104.

Abd-El- Samad, H. M. and N. Barakat. 1999. The response of lupine to exogenous application of $\mathrm{GA}_{3}$ and $\mathrm{ABA}$ under salt stress conditions. J. Union- Arab Biol., Cairo 7(B): 209-220. 
Al-Sobhi, O.A.; H.S. Al-Zahrani,and S.B. Al-Ahmadi. 2006. Effect of salinity on chlorophyll \& carbohydrate contents of calotropis crocera ceedlings. Scientific Journal of King Faisal University (Basic and Applied Sciences), 7 (1): $1427 \mathrm{H}$.

Almodares, A.; M. R. Hadi and B. Dosti. 2008. The effects of salt stress on growth parameters and carbohydrates contents in sweet sotghum. Res. J. of Environ. Sci., 2(4): 298- 304.

Anderson, W.P.1975. Ion transport through roots. In J.G.Torrrey and D. T. Clarkson (eds). The Development and Function of Roots. Third Cabot Symposium. Academic Press. London, New York, San Francisco. P.437-463.

Ashour, N. I; M. O. Kabesh and I. El-Oksh. 1970. Effect of chloride salinity on absorption and distribution of $\mathrm{P}^{32}$ by sunflower plants. Agrochemical 14(3):462-468.

Balasubramanian, A.; P. S. Srinivasan and G. Kumaravlu. 1996. Modulation of certain physiological parameters to salinity in Casuarina equisetifolia seedlings inoculated with five different Frankia strains. J. Trop. For. Sci. $9(1): 16-22$.

Baker, D. D. and B. C. Mullen. 1992. Actionorhizal Symbioses. In Stacy, G. S. ;R. H. Burris and H. J. Evans, eds, Biological Nitrogen Fixation. P.259-292, Chapman\& Hall, New York.

Berry, A. M.; O. T. Harriot; R. A.Morreau; S. F. Osman; D. R. Benson and A. D. Johones.1993. Hopanoid lipid compose the Frankia vesicle envelope, presumptive barrier of oxygen diffusion to nitrogenase. Proceeding National Academy of Science 90: 6091-6994.

Bremmer, J.M., and Mulvaney.1982. Nitrogen- total. pp. 595-624 in A. L. Page et al. (eds.): Methods of Soil Analysis, Part 2, $2^{\text {nd }}$ ed. Monger. No. 9. ASA an SSSA, Madison, WI.

Cottrnie, A. 1980. Soil and plant testing as abasis of fertilizer recommendations. FAO, No. 38(2). Rome, Italy.

Dawson, J. O. and A. H. Gibson. 1987. Sensitivity of selected Frankia isolates from Casuarina, Allocasuarina and North American host plants to sodium chloride. Physiologia Plantarum 70(2): 727-278.

Deane-Drummond, C. E. and A. D.M. Glass. 1982.Studies of nitrate influx into barley roots by the use of ${ }^{36} \mathrm{CLO}_{3}$ as a tracer for nitrate. I. Interaction with chloride and other ions. Can. J. Bot. 60: 2147-2353.

Diem, H. G. and Y. R. Dommergues.1983.Casuarina. p. 317-342. In Schwintzer, C. R. and J. D. Tjepkema; The Biology of Frankia and Actinorhizal plants, Academic press, San Diego, USA.

Dullaart, J. 1970. The auxin content of root nodules and roots of Alunus glutinosa. J. Exp. Bot. 21: 974.

Dragested, J. 1990. Some results from Danish investigations in salt stress on trees Proceedings of the SNS Seminar stress in Nature, Oulanka, Finland, September, 11-14, 1989.

Dwived, S. K.; W. Ali and R. K. Pathak. 1996. Effect of sodicity on growth and mineral composition of tamarind (Tamaindus indica L.). Ann. Agric. Res., 17 (4): 447-49. 
EL-Settawy, A. A. A. and A. A. S. EL-Gamal. 2003. Effect of salinity stress on the growth of Casurina glauca sieber ex spring and nodulation endobiont Frankia. Alex. J. Agric. Res. 48(2): 149-156.

El-Siddig, K. and P. Ludder. 1994. N- nutrition and salinity tolerance in apple trees. Angeewandate Botanik Berchte 5: 184-188.

Gauch, H. G. and C. H. Wadleight. 1962. Effect of high concentrations of sodium, calcium, chloride and sulfate on ionic absorption by bean plants. Soil Sci., 59 (3): 139-153.

Glass, A. D. M. and M. Y. Siddiqi. 1985. Nitrate inhibition of chloride influx in barley: Implications for proposed chloride homeostat. J. Exp. Bot. 36: 556-566.

Hartzendorf, $\mathrm{T}$ and $\mathrm{H}$. Rolletschek. 2001. Effects of $\mathrm{NaCl}$-salinity on amino acid and carbohydrate contents of Phragmites australis. Aquatic Botany, 69(2-4): 195-208.

KafKafi, U.; N. Valoras and J. Letey. 1982. Chloride interaction with nitrate and phosporus nutrition in tomato (Lycopersicion esculentum L.). Plant Nutrit. 5: 1369-1385.

Khamzina, A.; J. P.A. Lamers and P. L.G. Vlek. 2009. Nitrogen fixation by Elaeagnus angustifolia in the reclamation of degraded croplands of Central Asia. Tree Physiology: 29(6): 799-808.

Kundsen, D; G. A. Peterson and P. E. Pratt. 1982. Lithium, sodium, and potassium. P. 225-246. In A.L. Page et al. (eds.): Methods of Soil Analysis. Part 2, $2^{\text {nd }}$ ed. Monoger. No. 9. ASA and SSSA, Madison, WI.

Kurdali, F and F. Al-Ain. 2002. Effect of different water salinity on growth, nodulation, $\mathrm{N}$ - fixation by Dhaincha and on growth of sunflower using a ${ }^{15} \mathrm{~N}$-Tracer technique. J. Plant Nutrition, 25(11): 2483- 2498.

Marcar, N. E.; P. Dart and C. Sweeney. 1991. Effect of root-zone salinity on growth and chemical composition of Acacia ampliceps B. R. Maslin, Acacia auriculiformis, Acacia cunn. Ex Benth and Acacia mangium willd. at two nitrogen levels. New Phytol. 199 (4): 567-574.

Langdale, G. W. and J. R. Thomas. 1971. Soil salinity effects in absorption of nitrogen, phosphorus and protein synthesis by coastal Bermoda grass. Agron. J., 63: 708-711.

Miller, K. J. and J. M. Wood. 1996. Osmoadaptation by rhizosphere bacteria. Ann. Rev. Microbiol. 50:101-136.

Mahmood, S. T. and A. Mahmmood.1989. Effect of seawater salinity on nodulation and nitrogen fixation in Prosopis julifflora (Swartz) DC. Pakistan J. Botany 21 (1):68-73.

Munns, R. and A. Termaat. 1986. Whole plant responses to salinity. Aust. J. Physiol. 13: 143.

Munoz, G. E.; P. W. Barlow and B. Palma. 1996 .Effect of sea water on root of Prosopis alba (Leguminosae) seedlings. Phyton 59(1/2):55-63.

Olsen, S. R. and L. E. Sommers. 1982. Phosphorus. p. 403-430. In A.L. Page et. al. (eds). Methods of Soil Analsis part2. $2^{\text {nd }}$ ed. Agron. Monoger. No.9. ASA and SSSA, Madison, WI.

Panchban, S; R. Katawatin and P. Sirsataporn.1989. Effect of salinity on growth of fast growing trees. Khon Kaaen Agric. J., 17 (2): 91-99. 
Papadopoulos, I. and V. V. Rendig.1983. Interactive effects of salinity and nitrogen on growth and yield of tomato plants. Plant and Soil, 73(1): 4757.

Pawlowski, K.; A. Ribeiro; C. Guan; A. Kammen; A. Akkermans and T. Bisseling. 1993. Different gene expression in root nodules of Alnus glutinosa. Nitrogen Fixation with non-legume, The 6th International Symposium on Nitrogen Fixation with Non-Legumes, Ismailia, Egypt, 610 Sep. 1993, pp. 185-190.

Pongskul, W.; S. Wanapat; P. Mangprom and S. Sirimukdakul.1988. Responses of four tamarind (Tamarindus indica Lino) to different salinity levels. Kohn Kaen Agric. J. 18(2): 72-79.

Redell, P. H.; H. G. Diem and Y. R. Dommergues. 1991. Use of actinorhizal plants in arid and semiarid environments. p. 469-484. In D. Dekker, Semi Arid Desert Soils Resources and Reclamation.Berlin, Germany.

Rhoades, J. D. 1982. Soluble Salts. p.170-181. In A.L. Page et. al. (eds). Methods of Soil Analsis part2. $2^{\text {nd }}$ ed. Agron.Monoger. No. 9. ASA and SSSA, Madison, WI.

Roy, S.; D. P. Khasa and C. W. Greer. 2007. Combining alders, frankiae, and mycorrhizae for the revegetation and remediation of contaminated ecosystems. Can. J. Bot. 85(3): 237-251.

Salehi, M.; F. Salehi; K. Poustini and H. Heidari-Sharifabad. 2008. The effect of salinity on the nitrogen fixation in 4 cultivars of Medicago sativa L. in the seedling emergence stage. Res. J. Agric. Biological Sci., 4(5): 413415.

Silver, W.S.; F. E. Bendana and R. D. Powell. 1966. Root nodule symbiosis: The relation of auxin to root geotropism in root nodules of nonlegumes. Physiol. Plant 19: 207-218.

Steel, R. G. D. and T. H. Torrie. 1980. Principles and Procedures of Statistics. Mc Graw- Hill book, N. Y., USA, $2^{\text {nd }}$ edition.

Tani, C and H. Sasakawa. 2000. Salt tolerance of Elaegenus macrophylla and Frankia Emal strain isolated from the root nodules of $E$. macrophlla. Soil Sci. and Plant Nutr. 46 (4): 927-937.

TieHe and G. Cramer. 1993. Growth and ion accumulation of two rapidcycling Brassica species differing in salt tolerance. Plant and Soil 153: 19-31.

van Hoorn, J. W.; N. Katerji; A. Hamdy and M. Mastrorilli. 2001. Effect of salinity on yield and nitrogen uptake of four grain legumes and on biological nitrogen contribution from the soil. Agricultural water management, 51(2): 87-98.

Walker, R. R. 1989. Growth, photosynthesis and distribution of chloride, sodium and potassium ions in salt affected quandong (Sanataum acuminatum). Australian J. Plant Physiol. 16(4): 365-377.

Watad, A. E. A.; L. Reinhold and H. R. lerner. 1983. Comparison between a stable $\mathrm{NaCl}$-selected Nicotiana cell line and wild type K, Na and proline pools as a function of salinity. Plant Physiol., 73:624-629. 
تـأثير الفرانكيـا المحفزة لتكـوين العقدين على تحمـل نباتـات الكازوارينـا البيضـاء

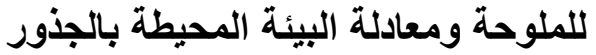

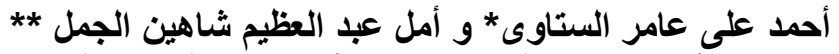

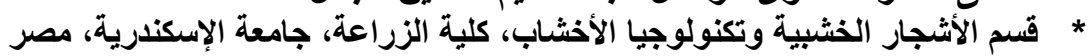

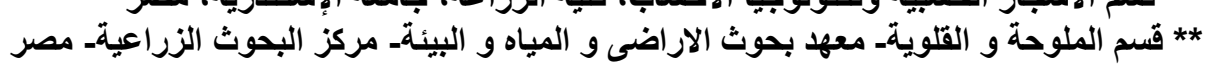

تهدف هذه الدراسة بحث تأثير الفرانكيا المثبتة للنيتروجين على تحمل النبات للملوحة

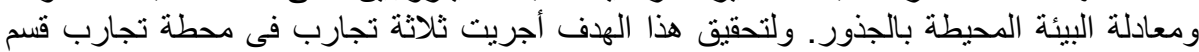

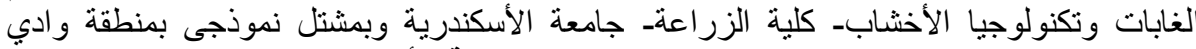

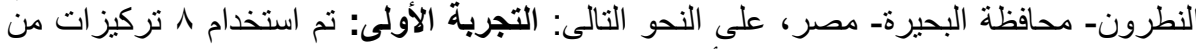

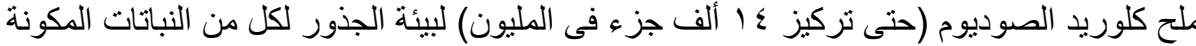

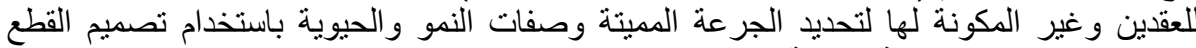

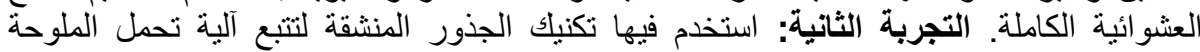

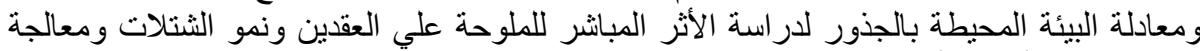

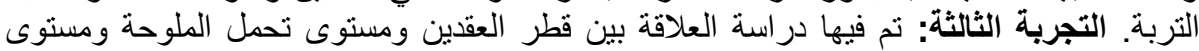

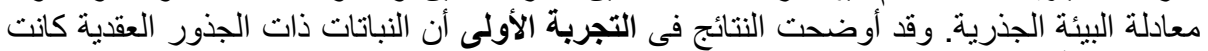

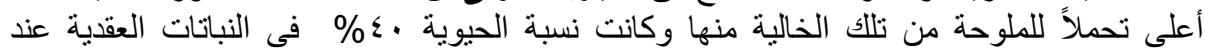

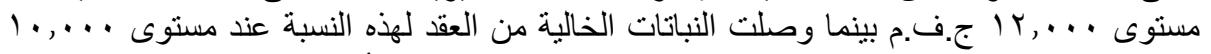
ج.ف.م من كلوريد الصوديوم- وكان معدل النمو فى النباتات العقدية أعلى من مثيله في غير النير العقدية

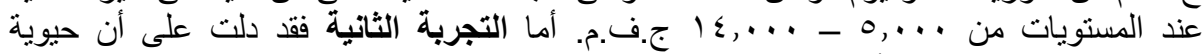

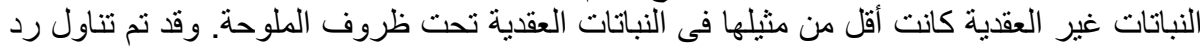

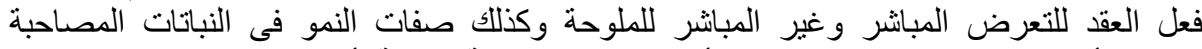

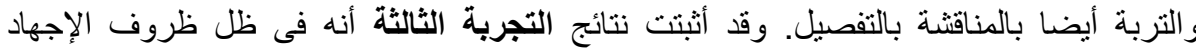

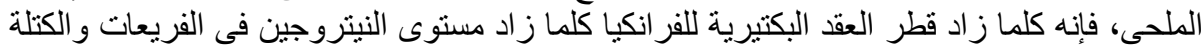

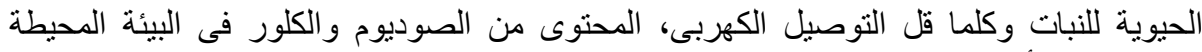

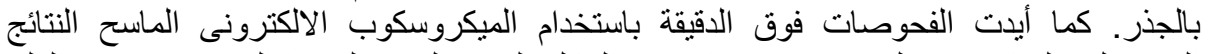

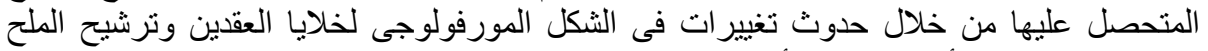

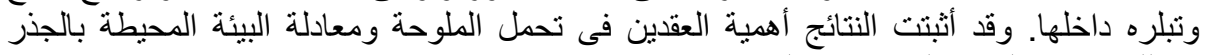
وكذلك صفات النمو و الحيوية في الثنتلات. 
Table 2: Survival, growth rate (GR), shoot dry matter (SDM), root dry matter (RDM), total dry matter (TDM) and nodule dry matter (NDM) of nodulated and unnodulated plants treated with 8 levels of salinity $\left(S_{1}\right.$, $S_{2}, \ldots \ldots \ldots$ and $\left.S_{8}\right)$.

\begin{tabular}{|c|c|c|c|c|c|c|c|c|c|c|c|c|c|c|c|c|c|}
\hline & \multicolumn{8}{|c|}{ unnodulated plants } & \multicolumn{8}{|c|}{ nodulated plants } & \multirow{2}{*}{ LSD } \\
\hline & $\mathbf{S}_{1}$ & $\mathrm{~S}_{2}$ & $\mathrm{~S}_{3}$ & $\mathbf{S}_{4}$ & $\mathrm{~S}_{5}$ & $\mathbf{S}_{6}$ & $\mathrm{~S}_{7}$ & $\mathbf{S}_{8}$ & $\mathbf{S}_{1}$ & $\mathbf{S}_{2}$ & $\mathrm{~S}_{3}$ & $\mathbf{S}_{4}$ & $\mathrm{~S}_{5}$ & $\mathbf{S}_{6}$ & $\mathrm{~S}_{7}$ & $\mathbf{S}_{8}$ & \\
\hline Survival (\%) & 100.00 & 80.00 & 80.00 & 80.00 & 60.00 & 40.00 & 20.00 & 00.00 & 00.00 & 10.00 & 100.00 & 100.00 & 100.00 & 100.00 & 40.00 & 20.00 & 15.55 \\
\hline GR (cm/month) & 4.22 & 4.00 & 3.61 & 2.25 & 2.00 & 1.05 & 0.35 & 0.30 & 6.00 & 6.30 & 4.80 & 5.15 & 5.35 & 5.05 & 4.25 & 3.20 & 1.62 \\
\hline SDM (g) & 1.23 & 1.33 & 1.43 & 1.08 & 0.94 & 0.82 & 0.85 & 0.62 & 4.13 & 5.52 & 5.52 & 7.82 & 8.05 & 7.21 & 6.66 & 3.60 & 1.35 \\
\hline RDM (g) & 0.64 & 0.70 & 0.86 & 2.13 & 0.73 & 0.61 & 0.57 & - & 1.91 & 2.02 & 2.02 & 2.85 & 3.15 & 2.34 & 3.55 & 2.26 & 0.85 \\
\hline TDM (g) & 1.87 & 2.03 & 2.29 & 3.21 & 1.67 & 1.43 & 1.32 & 1.35 & 6.04 & 7.24 & 7.24 & 9.69 & 11.10 & 9.55 & 10.21 & 5.85 & 1.22 \\
\hline NDM (g) & - & - & - & - & - & - & - & - & 0.42 & 0.45 & 0.43 & 0.43 & 0.47 & 0.43 & 0.20 & 0.21 & 0.20 \\
\hline
\end{tabular}

